\title{
13. PETROGRAPHY AND PHASE CHEMISTRY OF BASALTS FROM DSDP LEG 34: NAZCA PLATE
}

\author{
Louis J. Mazzullo, A.E. Bence, and J.J. Papike, Department of Earth and Space Sciences \\ State University of New York, Stony Brook, New York
}

\begin{abstract}
Three sites drilled on the Nazca plate on DSDP Leg 34 recovered fresh basalts quite unlike those recovered from previous legs. The textures of these rocks range from vitrophyric to ophitic, with variolitic intergrowths and altered glass present even in the groundmass of the coarsest unit sampled, and are suggestive of fairly rapid cooling histories. Site 321 basalts are all uniformly fine grained, vesicular, and intersertal. Many samples from all sites are plagioclase phyric, and Hole 319A basalts appear to be largely plagioclase and olivine phyric. Fresh relicts of olivine phenocrysts were recognized only in Hole 319A basalts, and olivine crystallization may have persisted into the groundmass in some Hole 319A basalts.

The feldspars are K-poor (mainly $<1 \%$ Or) plagioclases in all Leg 34 samples, and feldspar apparently crystallized in all samples during two or three major stages. The pyroxenes are aluminous augites and pigeonites which crystallized in one or two major stages. The rather strong chemical zonation in both these phases is also indicative of fairly rapid cooling. Site 321 pyroxenes are distinctive with respect to changes in the amounts of components other than Wo-En-Fs with crystallization.

Phase chemical and textural data allow the delineation of at least two major cooling units within the depth range of Hole 319A samples, two cooling units represented by Hole 320B samples (out of many reported), and at least two cooling units within the depth range of Site 321 samples, even in the absence of textural evidence for such delineations.
\end{abstract}

\section{INTRODUCTION}

DSDP Leg 34 sampled parts of the Nazca plate off the western coast of South America (Figure 1a). Three sites were drilled in an attempt to core deeply into basement rock, but technical problems prevented the desired extensive penetration. The basalts which were recovered from the Nazca plate, however, are among the freshest samples to date from the DSDP expeditions, and their relative freshness facilitates comprehensive petrographic and phase chemical studies.

Stratigraphic sections for each of the three sites sampled are presented in Figure $1 \mathrm{~b}$ and show the locations of the samples available for this study. The amount of basalt recovered from each basalt section is indicated by the dark patterns.

Hole $319 \mathrm{~A}$ is located on the western flank of the extinct Galapagos Rise on crustal rocks dated by paleontological study of overlying sediments at about 15 m.y. (Hart et al., 1974). The first basalt was encountered at approximately 98 meters below the water-sediment interface and was continously cored for 59 meters before the hole was abandoned (Figure 1b); however, only 25\% of the basalt was recovered. Shipboard measurements of densities, seismic velocities, and water contents all suggest rather fresh basalt throughout the cored section (Chapter 3, this volume). On the basis of textural changes, the shipboard scientists divided the basalt section (319A) into six definite cooling units and at least five additional thinner units. The major cooling units are 15.6 and 12.5 meters thick (Figure $1 \mathrm{~b}$ ). Rapid cooling of the margins of flow units is suggested by the finegrained variolitic nature of some samples and the abundance of glass fragments recovered from the core catchers; however, no contact zones were actually recovered (Chapter 3, this volume). Preliminary observations by the shipboard scientists suggest that the basalts at this site represent a suite of rapidly cooled, pillowed to massive flows, erupted within a short period of time.

Hole 320B cored a series of about nine pillows and thin flows beneath sediment dated at approximately 30 m.y. old. Although the basalts are more altered than those in Hole 319A, they nevertheless are less altered than expected for crustal rocks of this age. Basalt was encountered at about 154 meters below mudline and was cored for about 28 meters with poor recovery (Figure 1b).

Site 321 penetrated approximately 10 meters of basalt, 5 meters of which was recovered. The basalt section covers at least two cooling units (M. Bass, personal communication, 1974). The oldest overlying sediment is dated at 40 m.y. (Hart et al., 1974). The basalt, which was encountered 125 meters below mudline, was not quite as fresh as that from Hole 319A.

The unusual freshness of both Hole 319A and Site 321 basalts (relative to other deep-sea basalts) is one line of evidence which suggests that these rocks may be 


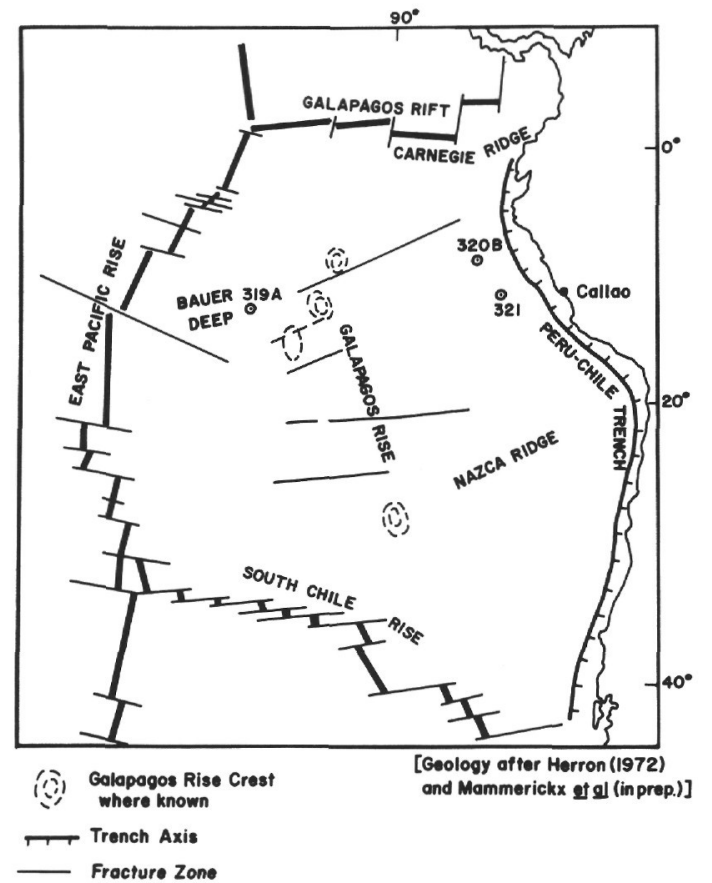

Figure 1a. Index map. DSDP Leg 34.

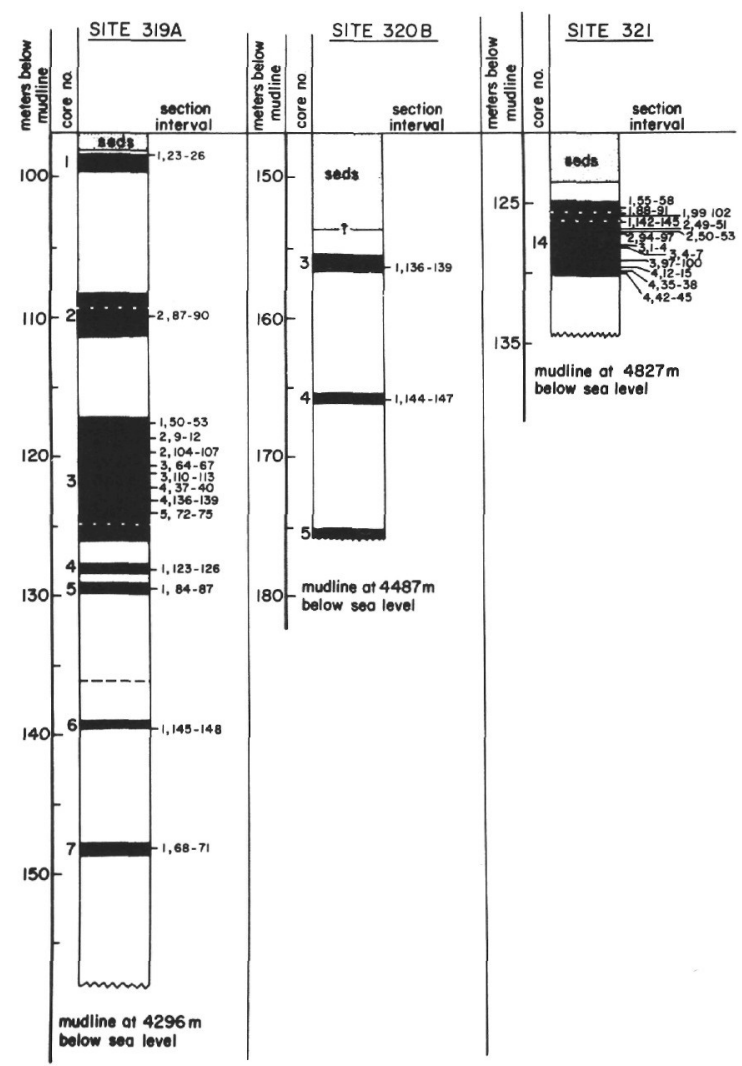

Figure 1b. Lithologic summary of basalt sections of Holes $319 \mathrm{~A}, 320 \mathrm{~B}$, and Site 321, showing locations of samples available in the sections and sample numbers. Dark areas in basalt represent recovered cores, and dashed lines delineate cooling units suggested by textural and phase chemical criteria. products of young off-ridge volcanism (Hart et al., 1974). Recent age determinations, however, are compatible with the ages of overlying (basal) sediments (S.R. Hart, personal communication, 1975). Site 321 basalts are quite vesicular and, in some of our samples, amygdaloidal. $\mathrm{Sr}$ concentrations suggest that the total basalt section at each site is genetically related (Hart, 1974). The mineralogy and bulk chemistry of all Leg 34 basalts are similar to those of tholeiitic ridge basalts, and, furthermore, all basalts appear to be typical largeion-lithophile (LIL)-depleted ridge tholeiites (Bunch and La Borde, 1974; Thompson et al., 1974; Fein, 1974; Hart, 1974).

This report presents preliminary petrographic and phase chemical data for representative basalts of Leg 34 . Of the 29 samples available for this study (Figure 1b), 16 were chosen for phase chemical analysis to represent as many of the reported cooling units as possible, and, in the case of Hole $320 \mathrm{~B}$, include all samples available to us.

\section{PETROGRAPHY}

\section{General}

A pproximately in decreasing order of abundance, Leg 34 basalts contain plagioclase, clinopyroxene, titanomagnetite, smectite, olivine, ilmenite, calcite, sulfides, Fe-oxides (goethite and hematite), and chromian spinel. Textures range from vitrophyric, through intersertal and variolitic, to subophitic and ophitic. Many samples are porphyritic, with phenocrysts of plagioclase. In some samples, olivine (mostly as smectite pseudomorphs) or clinopyroxene accompanies plagioclase as a phenocryst phase.

In all samples studied, euhedral to subhedral feldspar phenocrysts are normally zoned throughout. Late-stage feldspars vary from zoned euhedral laths to anhedral interstitial grains. Slender plagioclase crystals are characteristic of the vesicle-filling stage in some samples. Where present, pyroxene microphenocrysts are euhedral to subhedral and only slightly zoned, whereas interstitial pyroxenes show strong chemical zonation. Pyroxenes, where in contact with plagioclase, are depleted in $\mathrm{Ca}$, and this depletion causes an obvious change in birefringence near the contacts of these two phases over as much as an order of interference color.

In all samples the mesostasis late-stage residuum is altered in varying degrees to smectite, arising from one or two phases of secondary alteration (Bass, 1974). The mesostasis of the finer grained samples may represent devitrified or fresh glass which has subsequently been altered to smectite. In many samples, very fine grained quench plagioclase, pyroxene, and magnetite are commonly constituents of the late-stage mesostasis.

Table 1 presents a summary of the petrographic features of the Leg 34 basalts studied for this report. Modal abundances of the major phases are listed in Table 1 and major primary modal mineralogy is plotted for Hole 319A and Site 321 in Figure 2. During point counting, no effort was made to distinguish the smectite which occurs as an alteration product of early crystallizing phases from the smectite of the altered groundmass. Inasmuch as plagioclase and clinopyroxene are only 
TABLE 1

Summary of Petrographic Features of Leg 34 Basalts

\begin{tabular}{|c|c|c|c|c|c|c|c|c|}
\hline \multirow[b]{2}{*}{ Sample/Unit } & \multirow[b]{2}{*}{ Textural Types } & \multicolumn{5}{|c|}{ Modal Abundances (vol \%) } & \multirow[b]{2}{*}{$\begin{array}{l}\text { Paragenetic Sequence } \\
\text { (excluding alteration) }\end{array}$} & \multirow[b]{2}{*}{$\begin{array}{l}\text { Photomicrograph } \\
\text { Figure No. }\end{array}$} \\
\hline & & Plg. & cpx. & ol & opaques & $\begin{array}{l}\text { Altered } \\
\text { Mesostasis }\end{array}$ & & \\
\hline \multicolumn{9}{|l|}{ Hole 319A } \\
\hline $1-1,23-26 \mathrm{~cm}$ & $\begin{array}{l}\text { Porphyritic, } \\
\text { variolitic }\end{array}$ & $\sim 44$ & $\sim 39$ & 0.47 & 7.0 & 3.9 & $\begin{array}{l}\mathrm{Plg}+\mathrm{ol} \rightarrow \mathrm{plg}+\mathrm{cpx}+\mathrm{mt} \\
\rightarrow \mathrm{plg}+\mathrm{cpx}\end{array}$ & $3 \mathbf{a}$ \\
\hline 15.6-meter unit & $\begin{array}{l}\text { Porphyritic, } \\
\text { variolitic } \\
\text { through ophitic }\end{array}$ & $40.5-52$ & $25.5-35.5$ & $0-1.5$ & $6.2-10.5$ & $9.5-14.5$ & $\begin{array}{l}\mathrm{Plg}+\mathrm{ol} \rightarrow \mathrm{plg}+\mathrm{cpx}+\mathrm{ol} \\
\rightarrow \mathrm{plg}+\mathrm{cpx}+\mathrm{mt}+\mathrm{ilm} \pm \text { silica }\end{array}$ & $3 b, c$ \\
\hline 12.5-meter unit & $\begin{array}{l}\text { Porphyritic, } \\
\text { to interstitial }\end{array}$ & $38.5-41.2$ & $33.9-35$ & $0.64-2.5$ & $8.5-8.6$ & $12.8-14.8$ & $\begin{array}{l}\text { Cr.spinel } \rightarrow \text { ol }(?)+\text { plg } \rightarrow \text { plg } \\
+\operatorname{cpx}+\mathrm{mt}\end{array}$ & \\
\hline $6-1,145-148 \mathrm{~cm}$ & $\begin{array}{l}\text { Porphyritic, } \\
\text { intersertal } \\
\text { or vitrophyric; } \\
\text { flow orientation }\end{array}$ & 35 & 11.2 & - & 8.0 & 44.8 & $\mathrm{Plg}+\mathrm{cpx} \rightarrow \mathrm{plg}+\mathrm{cpx}+\mathrm{mt}$ & \\
\hline $7-1,68-71 \mathrm{~cm}$ & $\begin{array}{l}\text { Porphyritic, } \\
\text { intersertal }\end{array}$ & 30.5 & 33 & 0.2 & 9.6 & 22.9 & $\begin{array}{l}\mathrm{Plg}+\mathrm{ol} \rightarrow \mathrm{plg}+\mathrm{cpx} \rightarrow \\
\mathrm{plg}+\mathrm{cpx}+\mathrm{mt}\end{array}$ & \\
\hline \multicolumn{9}{|l|}{ Hole 320B } \\
\hline $3-1,136-139 \mathrm{~cm}$ & $\begin{array}{l}\text { Porphyritic, } \\
\text { vitrophyric } \\
\text { vesicular }\end{array}$ & 30.4 & 1.28 & - & 18.2 & 48.4 & $\mathrm{Plg} \rightarrow \mathrm{plg}+\mathrm{cpx}+\mathrm{mt}$ & $3 \mathrm{e}$ \\
\hline $4-1,144-147 \mathrm{~cm}$ & $\begin{array}{l}\text { Porphyritic, } \\
\text { variolitic } \\
\text { vesicular }\end{array}$ & 39.1 & 29.1 & - & 6.9 & 21.8 & $\begin{array}{l}\text { Cr.spinel } \rightarrow \text { plg } \rightarrow \text { plg } \\
+ \text { cpx }+ \text { mt }\end{array}$ & $3 d$ \\
\hline \multicolumn{9}{|l|}{ Site 321} \\
\hline All samples & $\begin{array}{l}\text { Vesicular, } \\
\text { porphyritic, } \\
\text { intersertal }\end{array}$ & $30-42$ & $27.5-36.5$ & - & $7.5-17.5$ & $14-20$ & $\begin{array}{l}\mathrm{Plg} \pm \mathrm{cpx} \rightarrow \mathrm{plg}+\mathrm{cpx} \\
+\mathrm{mt} \rightarrow \mathrm{plg}+\mathrm{cpx}+\mathrm{mt} \pm \text { silica }\end{array}$ & $3 \mathrm{f}$ \\
\hline
\end{tabular}

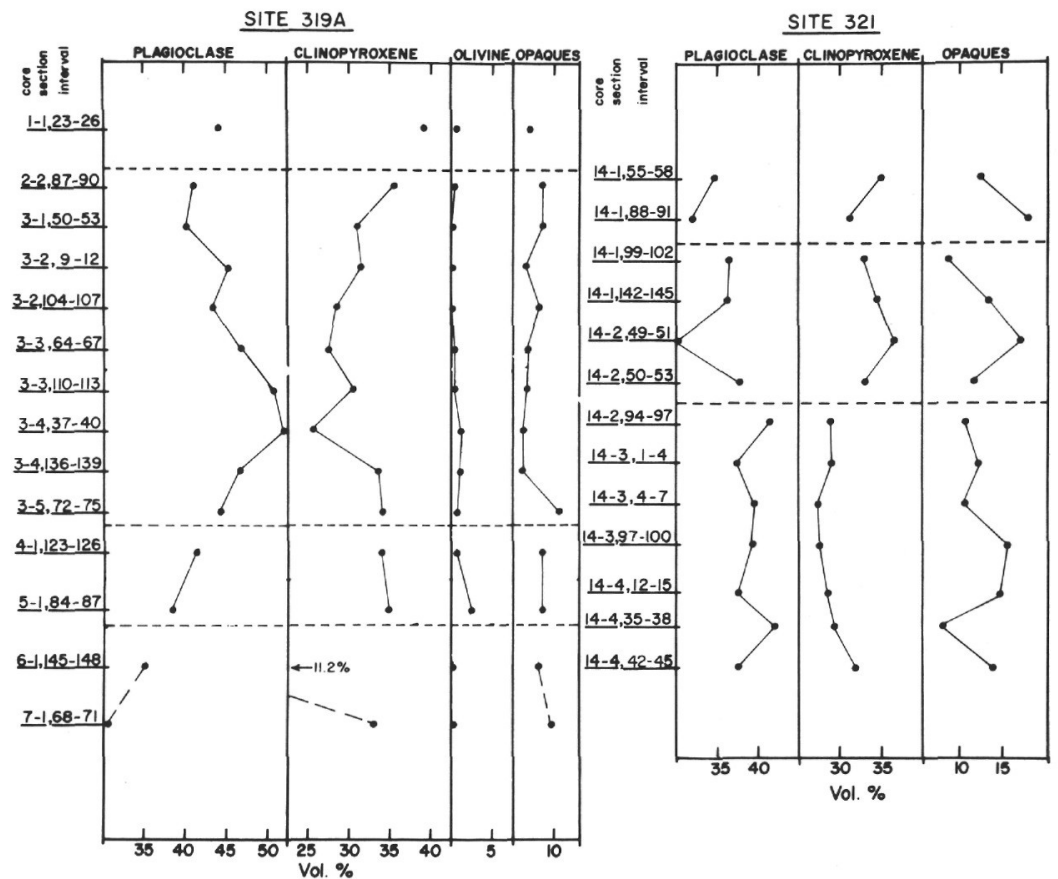

Figure 2. Modal mineralogy of the major primary phases at Hole $319 \mathrm{~A}$ and Site 321. The dashed horizontal lines delineate suggested cooling units. Dashed lines used to connect data points do not imply a continuous cooling unit in the two lowest samples of Hole 319A. No vertical scale.

very mildly altered in all the samples studied, the recognition of replacement alteration is relatively unambiguous. Plagioclase and pyroxene alteration products, therefore, were added to "fresh" modal values. Olivine modal values, however, are for "fresh" olivine only, as it is difficult to determine whether some smectite masses 
are actually pseudomorphs after olivine or massive smectite. The paragenetic sequences of the major units were determined by petrographic observation. Photomicrographs of representative textures of Leg 34 basalts are presented in Figure 3.

\section{Hole 319A}

The dashed lines in Figures $1 \mathrm{~b}$ and 2 delineate the cooling units suggested by textural and modal evidence. Most of the cooling units in Hole 319A are plagioclase and olivine phyric, although olivine phenocrysts in many samples are recognized only by the apparent reticulate nature of some subhedral smectite masses (Figure 3c). In some instances, olivine relicts are present within the centers of smectite pseudomorphs. Only Sample 319A-6-1, 145-148 cm, a quenched basalt, appears to be plagioclase and clinopyroxene phyric.

Glomeroporphyritic clots of plagioclase are common within the 15.6 meter cooling unit and within the 12.5meter unit, even in portions of the thicker unit where the groundmass is subophitic to ophitic. The fine grained sample directly below the 12.5-meter unit (6-1, 145-148 $\mathrm{cm})$ also contains glomeroporphyritic plagioclase.

Groundmass olivine has been identified in the 15.6and 12.5-meter units. In addition, skeletal olivine has been identified in the groundmass of other samples within the 15.6-meter unit not represented by our samples (M. Bass, personal communication, 1974), but groundmass olivine has not been identified in other Leg 34 samples reported here. The persistence of olivine into the groundmass stage has been noted by the shipboard scientists and was once considered as evidence that basalts containing olivine in the groundmass are not typical ridge-type tholeiites, but rather may be transitional or slightly alkali in character. Recent chemical analyses (for example, Bunch and La Borde, 1974) indicate, however, that major element chemistry is similar to that of ridge tholeiites, and the presence of groundmass olivine does not imply an off-ridge origin. The persistence of variolitic intergrowths into the groundmass of even the thickest unit of this site suggests rapid cooling of the basalts.

In the 15.6-meter cooling unit, textures vary systematically with position in the basalt column, ranging from medium-grained variolitic near the top, to coarse-grained ophitic near the middle (with ophitic pyroxenes up to $3 \mathrm{~mm}$ across their longest dimension), and medium-grained intergranular towards the bottom (Figures 3b, c). Our two representatives of the 12.5meter unit range in texture from medium-grained intergranular $(4-1,123-126 \mathrm{~cm})$ to medium-grained intersertal $(5-1,84-87 \mathrm{~cm})$. The coarse-grained nature of the 15.6-meter cooling unit, in addition to its lack of vesicles, suggests that this unit may have been emplaced as a shallow sill.

The uncertainty in modal values of plagioclase and clinopyroxene in Sample 319A-1-1, 23-26 cm is the result of the fine variolitic intergrowth of these two phases, which renders modal analysis difficult (Figure 3a).

\section{Hole 320B}

Hole 320B basalts are plagioclase phyric, with no identifiable fresh olivine in the paragenetic sequence.
Olivine has been found, however, in other parts of the basalt section (M. Bass, personal communication, 1974). These rocks, which are the most altered basalts of our samples, are also the finest grained (Figure 3d, e).

One occurrence of chromian spinel was noted in one Hole 320B sample (4-1, 144-147 cm). The spinel, included within a plagioclase phenocryst, is the only chromian spinel identified and analyzed in any of the Leg 34 samples.

\section{Site 321}

Our basalt samples from Site 321 are uniform in texture; all are vesicular and porphyritic with a fine-grained intersertal groundmass (Figure 3f). Vesicles are sometimes partially or completely filled by one or more of carbonates, smectite, and very fine-grained basalt. Phenocrysts are solely plagioclase, except for a few clinopyroxene microphenocrysts associated with plagioclase glomerocrysts. Olivine was not found.

The pronounced vesicularity and fine-grained groundmass throughout the section suggest an extrusive origin of these basalts. The K-Ar ages, which suggest that these basalts are younger than overlying sediments (Corliss et al., 1974), are thus suspect. Major element chemistry (Bunch and La Borde, 1974, and others) and $\mathrm{Sr}$ concentrations and low $\mathrm{Sr}^{87} / \mathrm{Sr}^{86}$ ratios (Hart, 1974) are strongly suggestive of ridge-type basalts at this site.

\section{PHASE CHEMISTRY}

Electron microprobe analyses were obtained for major phases of representative samples from the three sites using an automated four-spectrometer ARL-EMX-SM electron microprobe. Data were reduced according to Bence and Albee (1968). In some samples the fine grain sizes rendered probe analyses (especially for olivines and opaque oxides) impossible.

Samples analyzed include nine from Hole 319A, two from Hole 320B, and five from Site 321. Representative microprobe analyses are presented in Tables 2-5 and plotted on the various data displays.

\section{Pyroxenes}

The pyroxenes from Leg 34 basalts are aluminous (up to $\left.5.5 \mathrm{wt} \% \mathrm{Al}_{2} \mathrm{O}_{3}\right)$ augites $\left(\mathrm{WO}_{46-36} \mathrm{En}_{48-15} \mathrm{~F}_{56-49}\right)$ and pigeonites (Wo9-15 $\mathrm{En}_{69-57} \mathrm{Fs}_{22-28}$ ) which in most samples are characterized in plane light by a distinct light brown coloration. The range of components other than $\mathrm{CaSiO}_{3}(\mathrm{Wo})-\mathrm{MgSiO}_{3}(\mathrm{En})-\mathrm{Fe}^{2+} \mathrm{SiO}_{3}(\mathrm{Fs})$, hereafter referred to as "others" (for example, Papike et al., 1974), is from $5.1 \%$ to $26 \%$ in the augites and $3.1 \%$ to $3.2 \%$ in the pigeonites. Pigeonite occurs as discrete grains in the groundmass and, more commonly, in sectors within augite crystals.

In all the Leg 34 samples, the pyroxenes trend towards $\mathrm{Fe}$ enrichment with crystallization, although the trend in terms of $\mathrm{Ca}$ content is variable. "Other" elements in all samples are largely $\mathrm{Al}$ and $\mathrm{Ti}$, with lesser amounts of $\mathrm{Na}$ and $\mathrm{Fe}^{3+}$ and trace amounts of $\mathrm{Cr}$. "Other" components were characterized and $\mathrm{Fe}^{3+}$ estimated by the pyroxene data reduction method of Papike et al. (1974).

\section{Hole 319A}

Hole 319A pyroxenes are characterized by a general decrease in "others" with crystallization (Figure 4 and 


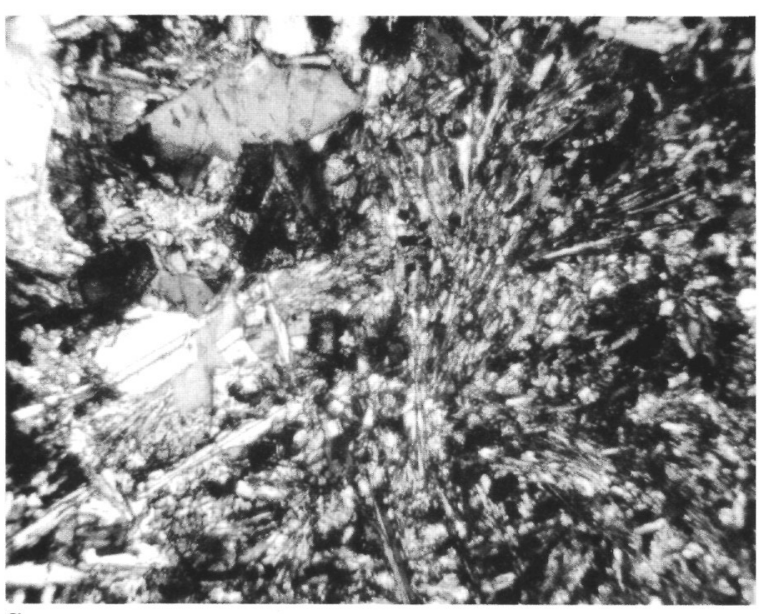

a
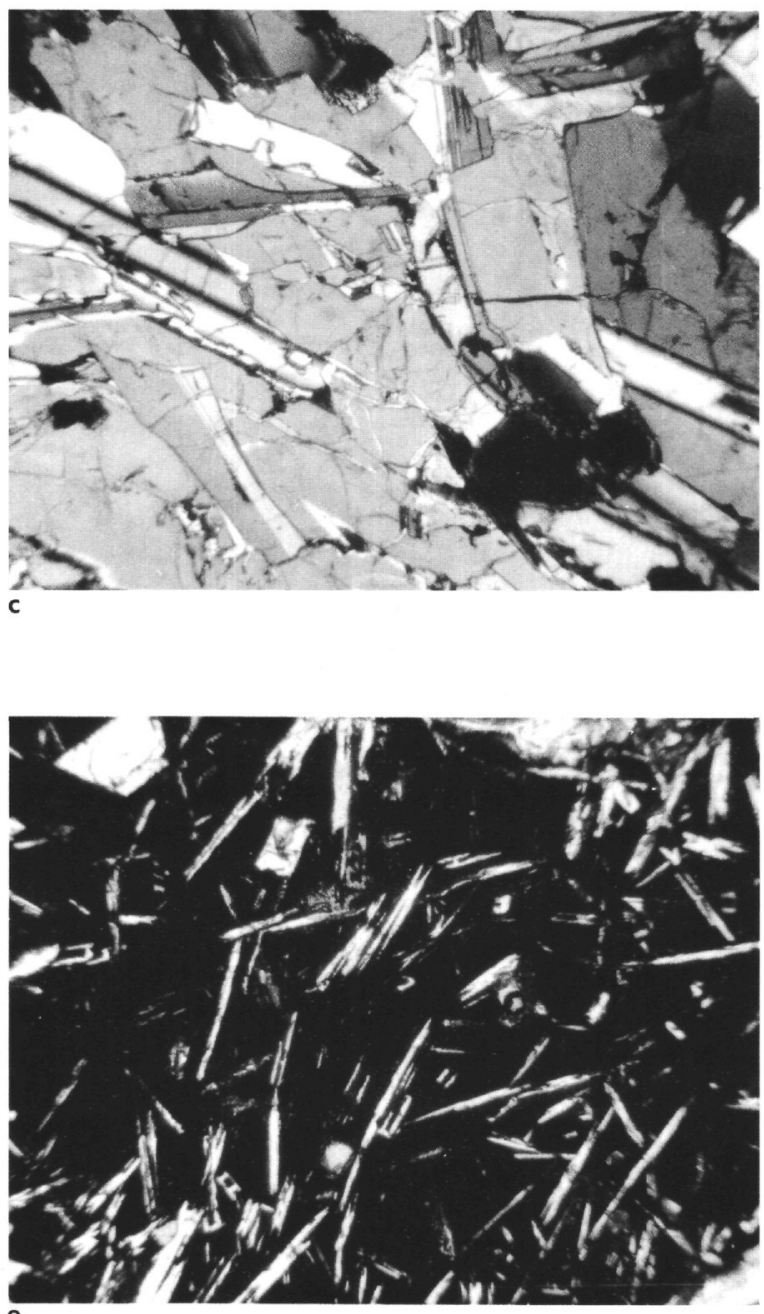

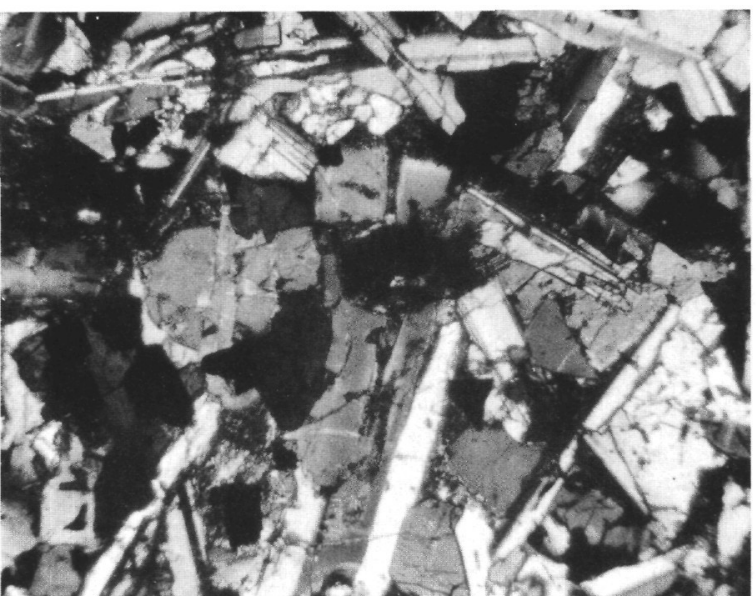

b
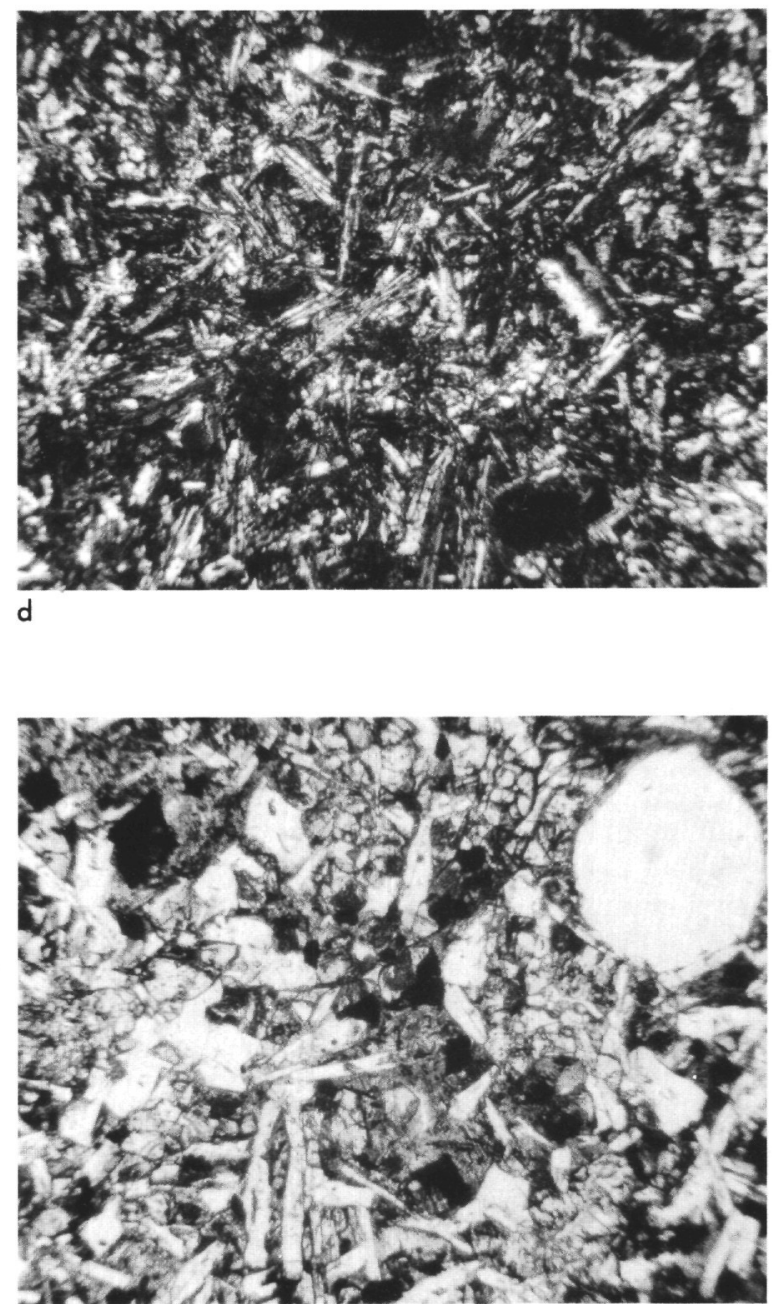

Figure 3. Photomicrographs showing representative textures of Leg 34 basalts; horizontal dimension is 1.4 mm. (a) Sample 319A-1-1, 23-26 cm, under crossed nicols, showing late-stage, fine-grained variolitic intergrowths of plagioclase and pyroxene. (b) Sample 319A-3-1, 50-53 cm, under crossed nicols, showing intergranular to subophitic texture developed in parts of the 15.6-meter cooling unit at Hole 319A. (c) Sample 319A-3-3, 64-67 cm, under crossed nicols, showing well-developed ophitic texture in proximity to the center of the 15.6-meter cooling unit. Subhedral dark mass in the lower right area of the photomicrograph is a smectite pseudomorph after olivine which has been plucked out by polishing. (d) Sample 320B-4-1, 144-147 cm, under crossed nicols, showing very fine-grained vesicular and variolitic texture. (e) Sample 320B-3-1, 136-139 $\mathrm{cm}$, under plane light, showing vesicular, vitrophyric texture. (f) Sample 321-13-3, 4-7 cm, under plane light, showing vesicular intersertal texture typical of all Site 321 samples. The vesicle in the upper right is filled with calcite. 
Table 2A) along an Fe-enrichment trend. Pyroxenes in both the 15.6-meter unit and the 12.5-meter unit show initial $\mathrm{Ca}$ depletion followed by enrichment in $\mathrm{Fe}$ relative to $\mathrm{Ca}$. The same relationships pertain to Sample 1-1, 23-26 cm, whereas Sample 7-1, 68-71 cm shows a Ca-depletion trend simultaneous with $\mathrm{Fe}$ enrichment (Figure 4). Initial pyroxenes near the bottom of the 12.5meter unit are enriched in $\mathrm{Mg}$ and "others" relative to those near the top of this unit (Figures 4 and 5).

Although "others" decrease with Fe enrichment, the relative proportions of sodium in the pyroxene $\mathrm{M}(2)$ site (NaM2), tetrahedral aluminum (A14), and titanium (Ti) change such that the trend is away from the A14 apex of the "others" triangular plot (Figure 6).

Figure 7 shows that total Al decreases with Fe enrichment. In addition, there are two different trends in this behavior depending on the type of sector zoning in the pyroxene.

\section{Hole 320B}

The two samples available for Hole 320B, approximately 10 meters apart in the section, probably represent two separate cooling units out of the 10 cored at this site. Although data on the upper sample (3-1, $136-139 \mathrm{~cm}$ ) are limited because of its extremely finegrained nature, the data available suggest that the pyroxenes here are richer in $\mathrm{Ca}$ and in "others" (Table 2B) than those in the lower sample (4-1, 144-147 cm). For both samples, the trend is away from the A14 apex on the Ti-NaM2-A14 plot as a function of Fe enrichment (Figure 6), with pyroxenes in the lower sample being relatively more enriched in A14 initially than those in the upper sample. Pyroxenes in the upper sample are enriched in $\mathrm{Fe}^{3+}$ relative to those in the lower sample (Table 2B and Figure 5). Total aluminum appears to vary significantly in the lower sample, showing an initial decrease followed by a sharp increase (Figure 7).

\section{Site 321}

The percentages of "other" components in Site 321 pyroxenes do not show a well-defined decrease with crystallization, as shown in Hole 319A pyroxenes. In fact, two samples show a marked increase in "others" with Fe enrichment (Figure 4), whereas Samples 14-4,

TABLE 2A

Representative Pyroxene Microprobe Analyses, Hole 319A

\begin{tabular}{|c|c|c|c|c|c|c|c|c|c|c|c|c|c|c|c|}
\hline \multirow[b]{2}{*}{$\mathrm{SiO}_{2}$} & \multicolumn{3}{|c|}{$1-1,23-26 \mathrm{~cm}$} & \multicolumn{5}{|c|}{ 15.6-Meter Unit } & \multicolumn{3}{|c|}{ 12.5-Meter Unit } & \multicolumn{2}{|c|}{$6-1,145-148 \mathrm{~cm}$} & \multicolumn{2}{|c|}{$7-1,68-71 \mathrm{~cm}$} \\
\hline & 51.2 & 53.2 & 47.2 & 50.6 & 50.8 & 50.7 & 49.0 & 52.8 & 49.3 & 48.6 & 52.9 & 51.9 & 51.8 & 49.3 & 48.9 \\
\hline $\mathrm{Al}_{2} \mathrm{O}_{3}$ & 4.56 & 2.01 & 2.12 & 3.24 & 2.52 & 2.01 & 1.46 & 0.71 & 4.58 & 2.34 & 1.66 & 2.27 & 2.97 & 4.44 & 3.00 \\
\hline $\mathrm{TiO}_{2}$ & 0.81 & 0.39 & 1.38 & 1.11 & 1.11 & 1.37 & 0.93 & 0.55 & 1.21 & 1.50 & 0.72 & 0.50 & 0.60 & 1.59 & 1.90 \\
\hline $\mathrm{Cr}_{2} \mathrm{O}_{3}$ & 0.51 & 0.36 & - & 0.17 & 0.05 & - & - & - & 0.27 & 0.03 & 0.09 & 0.63 & 0.94 & 0.40 & 0.03 \\
\hline "FeO" & 6.30 & 6.55 & 27.5 & 8.67 & 12.5 & 15.6 & 25.1 & 17.9 & 7.83 & 18.8 & 8.04 & 5.89 & 5.89 & 6.84 & 14.7 \\
\hline $\mathrm{MnO}$ & 0.18 & 0.20 & 0.67 & 0.23 & 0.25 & 0.43 & 0.62 & 0.53 & 0.19 & 0.52 & 0.25 & 0.06 & 0.14 & 0.15 & 0.31 \\
\hline $\mathrm{MgO}$ & 17.0 & 20.3 & 4.54 & 15.8 & 16.4 & 13.1 & 8.60 & 20.3 & 16.0 & 9.71 & 18.2 & 17.7 & 17.2 & 15.8 & 13.6 \\
\hline $\mathrm{CaO}$ & 19.4 & 15.7 & 15.3 & 20.8 & 15.3 & 18.0 & 14.6 & 7.21 & 20.9 & 18.7 & 18.4 & 20.8 & 20.4 & 20.7 & 17.4 \\
\hline $\mathrm{Na}_{2} \mathrm{O}$ & 0.13 & 0.09 & 0.12 & 0.20 & 0.17 & 0.16 & 0.11 & - & 0.23 & 0.23 & 0.09 & 0.25 & 0.26 & 0.28 & 0.26 \\
\hline$\Sigma$ & 100.09 & 98.80 & 98.83 & 100.82 & 99.10 & 101.37 & 100.42 & 100.00 & 100.51 & 100.43 & 100.35 & 100.00 & 100.20 & 99.50 & 100.10 \\
\hline $\mathrm{FeO}$ & 6.04 & 6.55 & 27.5 & 5.80 & 11.8 & 14.9 & 24.5 & 17.9 & 3.52 & 17.7 & 7.20 & 3.60 & 4.25 & 4.27 & 13.3 \\
\hline $\mathrm{Fe}_{2} \mathrm{O}_{3}$ & 0.29 & - & - & 3.19 & 0.68 & 0.82 & 0.71 & - & 4.78 & 1.23 & 0.93 & 2.54 & 1.82 & 2.85 & 1.54 \\
\hline $\mathrm{Si}$ & 1.873 & 1.947 & 1.925 & 1.857 & 1.909 & 1.905 & 1.929 & 1.966 & 1.806 & 1.880 & 1.934 & 1.896 & 1.890 & 1.823 & 1.853 \\
\hline $\mathrm{Al}^{\mathrm{IV}}$ & 0.127 & 0.053 & 0.075 & 0.140 & 0.091 & 0.089 & 0.068 & 0.031 & 0.194 & 0.107 & 0.066 & 0.098 & 0.110 & 0.177 & 0.134 \\
\hline$\Sigma \mathrm{TET}$ & 2.000 & 2.000 & 2.000 & 1.997 & 2.000 & 1.994 & 1.997 & 1.997 & 2.000 & 1.987 & 2.000 & 1.994 & 2.000 & 2.000 & 1.987 \\
\hline $\mathrm{Ti}$ & 0.022 & 0.011 & 0.042 & 0.031 & 0.031 & 0.039 & 0.028 & 0.015 & 0.033 & 0.044 & 0.020 & 0.014 & 0.016 & 0.044 & 0.054 \\
\hline $\mathrm{Al}^{\mathrm{VI}}$ & 0.069 & 0.034 & 0.027 & - & 0.020 & - & - & - & 0.004 & - & 0.005 & - & 0.018 & 0.017 & - \\
\hline $\mathrm{Cr}$ & 0.015 & 0.010 & - & 0.005 & 0.001 & - & - & - & 0.008 & 0.001 & 0.003 & 0.018 & 0.027 & 0.012 & 0.001 \\
\hline $\mathrm{Fe}^{3+}$ & 0.008 & - & - & 0.088 & 0.019 & 0.023 & 0.021 & - & 0.132 & 0.036 & 0.026 & 0.070 & 0.050 & 0.079 & 0.044 \\
\hline $\mathrm{Fe}^{2+}$ & 0.185 & 0.201 & 0.937 & 0.178 & 0.372 & 0.466 & 0.807 & 0.557 & 0.108 & 0.572 & 0.220 & 0.110 & 0.130 & 0.132 & 0.422 \\
\hline $\mathrm{Mn}$ & 0.006 & 0.006 & 0.023 & 0.007 & 0.008 & 0.014 & 0.021 & 0.017 & 0.006 & 0.017 & 0.008 & 0.002 & 0.004 & 0.005 & 0.010 \\
\hline $\mathrm{Mg}$ & 0.924 & 1.105 & 0.276 & 0.863 & 0.917 & 0.733 & 0.505 & 1.129 & 0.874 & 0.560 & 0.993 & 0.966 & 0.937 & 0.872 & 0.769 \\
\hline$\Sigma O C T$ & 1.229 & 1.367 & 1.305 & 1.172 & 1.368 & 1.275 & 1.382 & 1.718 & 1.165 & 1.230 & 1.275 & 1.180 & 1.182 & 1.161 & 1.300 \\
\hline $\mathrm{Ca}$ & 0.762 & 0.614 & 0.669 & 0.819 & 0.618 & 0.726 & 0.617 & 0.287 & 0.819 & 0.778 & 0.720 & 0.815 & 0.799 & 0.819 & 0.707 \\
\hline $\mathrm{Na}$ & 0.009 & 0.006 & 0.010 & 0.014 & 0.012 & 0.012 & 0.008 & - & 0.016 & 0.017 & 0.006 & 0.018 & 0.018 & 0.020 & 0.019 \\
\hline $\begin{array}{l}\text { Total } \\
\text { cations }\end{array}$ & $\overline{4.000}$ & 3.987 & 3.984 & 4.002 & 3.998 & $\overline{4.007}$ & $\overline{4.004}$ & $\overline{4.002}$ & $\overline{4.000}$ & 4.012 & $\overline{4.001}$ & 4.007 & 3.999 & 4.000 & 4.013 \\
\hline Quad & 87.3 & 94.7 & 92.5 & 86.0 & 90.9 & 91.1 & 93.2 & 96.9 & 80.6 & 89.3 & 93.3 & 90.2 & 89.0 & 82.3 & 86.5 \\
\hline "Others" & 12.7 & 5.3 & 7.5 & 14.0 & 9.1 & 8.9 & 6.8 & 3.1 & 19.4 & 10.7 & 6.7 & 9.8 & 11.0 & 17.7 & 13.4 \\
\hline Wo & 40.7 & 32.0 & 35.5 & 44.0 & 32.4 & 37.7 & 32.0 & 14.6 & 45.5 & 40.7 & 37.2 & 43.1 & 42.8 & 44.9 & 37.2 \\
\hline En & 49.4 & 57.6 & 14.7 & 46.4 & 48.1 & 38.1 & 26.2 & 57.2 & 48.5 & 29.3 & 51.4 & 51.1 & 50.2 & 47.8 & 40.5 \\
\hline Fs & 9.9 & 10.4 & 49.8 & 9.6 & 19.5 & 24.2 & 41.8 & 28.2 & 6.0 & 30.0 & 11.4 & 5.8 & 7.0 & 7.3 & 22.3 \\
\hline $\mathrm{Ti}$ & 14.0 & 15.3 & 33.5 & 16.6 & 23.2 & 27.8 & 26.6 & 33.1 & 13.7 & 26.0 & 21.4 & 10.6 & 11.4 & 18.4 & 26.1 \\
\hline $\mathrm{NaM}_{2}$ & 5.8 & 9.1 & 7.5 & 7.7 & 9.2 & 8.4 & 8.1 & - & 6.7 & 10.3 & 6.9 & 13.7 & 12.7 & 8.3 & 9.2 \\
\hline Al4 & 80.2 & 75.6 & 59.0 & 75.7 & 67.6 & 63.8 & 65.3 & 66.9 & 79.6 & 63.7 & 71.7 & 75.7 & 75.9 & 73.3 & 64.7 \\
\hline $\begin{array}{l}\text { Best name } \\
\text { for others }\end{array}$ & $\begin{array}{l}\text { CAAL- } \\
\text { CATS }\end{array}$ & $\begin{array}{l}\text { CAAL- } \\
\text { CATS }\end{array}$ & $\begin{array}{l}\text { CAF 2- } \\
\text { TAL }\end{array}$ & $\begin{array}{l}\text { CAF3- } \\
\text { CATS }\end{array}$ & $\begin{array}{l}\text { CAMG- } \\
\text { TAL }\end{array}$ & $\begin{array}{l}\text { CAMG- } \\
\text { TAL }\end{array}$ & $\begin{array}{l}\text { CAF 2- } \\
\text { TAL }\end{array}$ & $\begin{array}{l}\text { MG- } \\
\text { TAL }\end{array}$ & $\begin{array}{l}\text { CAF3- } \\
\text { CATS }\end{array}$ & $\begin{array}{l}\text { CAF2- } \\
\text { TAL }\end{array}$ & $\begin{array}{l}\text { CAMG- } \\
\text { TAL }\end{array}$ & $\begin{array}{l}\text { CAF3- } \\
\text { CATS }\end{array}$ & $\begin{array}{l}\text { CAF3- } \\
\text { CATS }\end{array}$ & $\begin{array}{l}\text { CAMG- } \\
\text { TAL }\end{array}$ & $\begin{array}{l}\text { CAMG- } \\
\text { TAL }\end{array}$ \\
\hline
\end{tabular}


TABLE 2B

Representative Pyroxene Microprobe Analyses, Hole 320B

\begin{tabular}{|c|c|c|c|}
\hline & $3-1,136-139 \mathrm{~cm}$ & $4-1,144$ & $147 \mathrm{~cm}$ \\
\hline $\mathrm{SiO}_{2}$ & 44.5 & 49.8 & 50.2 \\
\hline $\mathrm{Al}_{2} \mathrm{O}_{3}$ & 5.67 & 4.70 & 2.97 \\
\hline $\mathrm{TiO}_{2}$ & 4.05 & 1.67 & 1.58 \\
\hline $\mathrm{Cr}_{2} \mathrm{O}_{3}$ & 0.11 & 0.30 & 0.01 \\
\hline "FeO" & 11.2 & 9.56 & 15.1 \\
\hline $\mathrm{MnO}$ & 0.15 & 0.26 & 0.39 \\
\hline $\mathrm{MgO}$ & 10.9 & 13.7 & 13.2 \\
\hline $\mathrm{CaO}$ & 21.0 & 20.3 & 16.3 \\
\hline $\mathrm{Na}_{2} \mathrm{O}$ & 0.58 & 0.25 & 0.28 \\
\hline$\Sigma$ & 98.16 & 100.54 & 100.03 \\
\hline $\mathrm{FeO}$ & 9.29 & 9.16 & 15.1 \\
\hline $\mathrm{Fe}_{2} \mathrm{O}_{3}$ & 2.16 & 0.44 & - \\
\hline $\mathrm{Si}$ & 1.726 & 1.849 & 1.900 \\
\hline $\mathrm{A} 1 \mathrm{IV}$ & 0.260 & 0.151 & 0.100 \\
\hline$\Sigma$ TET & 1.986 & 2.000 & 2.000 \\
\hline $\mathrm{Ti}$ & 0.118 & 0.047 & 0.045 \\
\hline $\mathrm{A} 1 \mathrm{VI}$ & - & 0.055 & 0.032 \\
\hline $\mathrm{Cr}$ & 0.003 & 0.009 & - \\
\hline $\mathrm{Fe}^{3+}$ & 0.063 & 0.012 & - \\
\hline $\mathrm{Fe}^{2+}$ & 0.302 & 0.284 & 0.479 \\
\hline $\mathrm{Mn}$ & 0.005 & 0.008 & 0.012 \\
\hline $\mathrm{Mg}$ & 0.623 & 0.760 & 0.746 \\
\hline$\Sigma$ OCT & 1.114 & 1.175 & 1.314 \\
\hline $\mathrm{Ca}$ & 0.872 & 0.807 & 0.659 \\
\hline $\mathrm{Na}$ & 0.043 & 0.018 & 0.021 \\
\hline Total cations & 4.015 & 4.000 & 3.994 \\
\hline Quad & 74.0 & 84.9 & 89.9 \\
\hline Others & 26.0 & 15.1 & 10.1 \\
\hline Wo & 48.5 & 43.6 & 35.0 \\
\hline En & 34.7 & 41.1 & 39.6 \\
\hline Fs & 16.8 & 15.3 & 25.4 \\
\hline $\mathrm{Ti}$ & 28.1 & 21.6 & 27.1 \\
\hline $\mathrm{NaM} 2$ & 10.2 & 8.3 & 12.4 \\
\hline A14 & 61.7 & 70.1 & 60.5 \\
\hline $\begin{array}{l}\text { Best name } \\
\text { for others }\end{array}$ & CAMG-TAL & CAMG-TAL & CAMG-TAL \\
\hline
\end{tabular}

35-38 cm and 14-1, 55-58 $\mathrm{cm}$ show a small increase in "others." The strong increase in "others" in two of the samples is accompanied by an increase in $\mathrm{Ca}$ and is characteristic of the interstitial or vesicle-filling stage of crystallization in these two samples.

Most of the Site 321 pyroxenes show a decrease in tetrahedral $\mathrm{Al}$ (relative to $\mathrm{Ti}$ and $\mathrm{Na}$ ) with crystallization (Figure 6), but no discernible trend is evident for Sample 14-1, 99-102 cm. $\mathrm{Fe}^{3+}$ content is low in most of the pyroxenes of the samples and may show a slight increase with crystallization, possibly reflecting changes in $\mathrm{fO}_{2}$ in the later stages (Figure 5). This trend is in contrast to those observed at Holes 319A and 320B, where total $\mathrm{Al}$ and $\mathrm{Fe}^{3+}$ decrease with crystallization.

Figure 7 shows that in Samples 14-1, 99-102 cm and $14-2,50-53 \mathrm{~cm}$ there is an increase in total Al during the late stages of pyroxene growth. The two samples towards the bottom of the basalt section show an early increase in $\mathrm{Al}$, followed by a late decrease. These samples also show a zoning trend on both Figure 7 and the quadrilateral plot (Figure 4). The uppermost sample $(14-1,55-58 \mathrm{~cm})$ shows essentially constant total Al with $\mathrm{Fe}$ enrichment in the main pyroxene trend.

M. Bass (personal communication) suggests that only two cooling units are present at Site 321; the pyroxene crystallization trends presented in our study are inconclusive with respect to his suggestion, and more detailed analyses are in progress to determine whether pyroxene crystallization trends will be useful in delineating the two reported units.

\section{Intersite Variations}

In summary, Site 321 pyroxenes have proven somewhat unique among the three Leg 34 sites in terms of the changes in "other" components with crystallization. Whereas all samples from Holes 319A and 320B show a general decrease in "others" with crystallization, Site 321 pyroxenes almost always show a slight increase in "others" (Figure 5). The pyroxenes in Hole 320B and Site 321 are generally almost as strongly zoned as those in Hole 319A.

At all sites, $\mathrm{Cr}$ content of pyroxenes decreases with crystallization of pyroxenes to almost zero $\mathrm{Cr}$ (Table 2).

\section{Feldspars}

Feldspars from samples representing all three sites are plagioclase $\left(\mathrm{An}_{82}{ }_{24}\right)$ with little or no potassium feldspar component (Or) except in some late-stage (vesiclefilling) feldspars. "Fe" (total $\mathrm{Fe}$ as $\mathrm{Fe}^{2+}$ ) and $\mathrm{Mg}$ constitute important minor elements in the feldspars, with "Fe" $/(" \mathrm{Fe} "+\mathrm{Mg}$ ) varying from approximately 0.42 to 1.00. In general, "Fe" $/(" \mathrm{Fe} "+\mathrm{Mg})$ increases with increasing $\mathrm{Na}$ as $\mathrm{Mg}$ (generally) decreases. Interstitial Kfeldspar has not been found in any of the samples analyzed.

\section{Hole 319A}

Plagioclase feldspars throughout the basalt section of Hole 319A are characterized by an overlap of phenocryst rim compostions with the compositions of groundmass plagioclases (Figure 8 ). Within the limits of our analyses of the 15.6-meter cooling unit, plagioclase compositions among samples of the unit are fairly uniform, except in Sample 3-2, 104-107 cm, where phenocryst cores and rims are the most calcic in the unit. Ti-NaM2A14 diagrams for pyroxenes in this same cooling unit reveal that the initial $\mathrm{Na}$ contents in pyroxenes from Sample 3-2, 104-107 cm are slightly higher relative to $\mathrm{Ti}$ and A14 than in the other representative samples of this unit (Figure 6).

Within the 12.5 -meter cooling unit, plagioclases apparently become more calcic towards the top contact (Figure 8) concomitant with an increase in modal plagioclase toward the top (Figure 2). The extremely fine-grain size of Sample 6-1, 145-148 cm is reflected in the relatively narrow spread of feldspar compositions (An81-62).

The plagioclase in Hole 319A basalts generally contains very little $\mathrm{K}(<1 \% \mathrm{Or})$. The highest percentage of 
TABLE 2C

Representative Pyroxene Microprobe Analyses, Site 321

\begin{tabular}{|c|c|c|c|c|c|c|c|c|c|c|c|c|}
\hline \multirow[b]{2}{*}{$\mathrm{SiO}_{2}$} & \multicolumn{3}{|c|}{$14-1,55-58 \mathrm{~cm}$} & \multicolumn{3}{|c|}{$14-1,99-102 \mathrm{~cm}$} & \multirow{2}{*}{$\begin{array}{c}\begin{array}{c}14-2, \\
50-53 \mathrm{~cm}\end{array} \\
45.7\end{array}$} & \multicolumn{2}{|c|}{$14-4,12-15 \mathrm{~cm}$} & \multicolumn{3}{|c|}{$14-4,35-38 \mathrm{~cm}$} \\
\hline & 52.7 & 50.3 & 54.2 & 51.5 & 53.6 & 46.3 & & 51.5 & 50.1 & 52.6 & 49.2 & 51.1 \\
\hline $\mathrm{Al}_{2} \mathrm{O}_{3}$ & 2.14 & 2.16 & 0.75 & 3.19 & 0.73 & 5.35 & 5.47 & 2.95 & 2.25 & 2.30 & 2.68 & 1.87 \\
\hline $\mathrm{TiO}_{2}$ & 0.59 & 1.22 & 0.39 & 1.08 & 0.43 & 2.82 & 3.34 & 0.79 & 1.25 & 0.63 & 1.63 & 0.98 \\
\hline $\mathrm{Cr}_{2} \mathrm{O}_{3}$ & 0.36 & - & 0.05 & 0.18 & 0.04 & 0.01 & - & 0.29 & - & 0.30 & 0.02 & 0.01 \\
\hline "FeO" & 8.17 & 17.0 & 14.8 & 8.65 & 17.4 & 16.2 & 20.0 & 9.13 & 16.8 & 8.58 & 16.0 & 16.6 \\
\hline $\mathrm{MnO}$ & 0.21 & 0.40 & 0.31 & 0.18 & 0.45 & 0.40 & 0.46 & 0.26 & 0.41 & 0.23 & 0.42 & 0.47 \\
\hline $\mathrm{MgO}$ & 16.9 & 11.8 & 23.0 & 15.8 & 23.5 & 10.6 & 8.00 & 16.4 & 14.5 & 17.2 & 13.0 & 14.9 \\
\hline $\mathrm{CaO}$ & 18.8 & 17.6 & 7.6 & 18.7 & 4.59 & 18.2 & 17.0 & 19.2 & 14.0 & 18.8 & 16.6 & 13.5 \\
\hline $\mathrm{Na}_{2} \mathrm{O}$ & 0.16 & 0.17 & - & 0.20 & - & 0.25 & 0.22 & 0.13 & 0.11 & 0.18 & 0.19 & 0.13 \\
\hline$\Sigma$ & $\overline{100.03}$ & $\overline{100.65}$ & $\overline{101.10}$ & 99.48 & $\overline{100.74}$ & $\overline{100.13}$ & $\overline{100.19}$ & $\overline{100.65}$ & $\overline{99.42}$ & $\overline{100.82}$ & 99.74 & 99.56 \\
\hline $\mathrm{FeO}$ & 8.17 & 16.5 & 14.5 & 8.65 & 17.2 & 14.3 & 20.0 & 7.64 & 16.4 & 7.54 & 14.7 & 16.6 \\
\hline $\mathrm{Fe}_{2} \mathrm{O}_{3}$ & - & 0.51 & 0.34 & - & 0.24 & 2.18 & - & 1.65 & 0.47 & 1.15 & 1.41 & - \\
\hline $\mathrm{Si}$ & 1.939 & 1.916 & 1.965 & 1.907 & 1.958 & 1.776 & 1.785 & 1.892 & 1.911 & 1.919 & 1.877 & 1.939 \\
\hline $\mathrm{Al}^{\mathrm{IV}}$ & 0.061 & 0.084 & 0.032 & 0.093 & 0.031 & 0.224 & 0.215 & 0.108 & 0.089 & 0.081 & 0.120 & 0.061 \\
\hline$\Sigma$ TET & 2.000 & $\overline{2.000}$ & 1.997 & $\overline{2.000}$ & 1.989 & $\overline{2.000}$ & $\overline{2.000}$ & 2.000 & $\overline{2.000}$ & 2.000 & 1.997 & 2.000 \\
\hline $\mathrm{Ti}$ & 0.016 & 0.035 & 0.011 & 0.030 & 0.012 & 0.081 & 0.098 & 0.022 & 0.036 & 0.017 & 0.047 & 0.028 \\
\hline $\mathrm{Al}^{\mathrm{VI}}$ & 0.032 & 0.012 & - & 0.046 & - & 0.017 & 0.037 & 0.020 & 0.012 & 0.018 & - & 0.023 \\
\hline $\mathrm{Cr}$ & 0.010 & - & 0.001 & 0.005 & 0.001 & - & - & 0.008 & - & 0.009 & 0.001 & - \\
\hline $\mathrm{Fe}^{3+}$ & - & 0.015 & 0.009 & - & 0.007 & 0.063 & - & 0.046 & 0.014 & 0.032 & 0.040 & - \\
\hline $\mathrm{Fe}^{2+}$ & 0.251 & 0.526 & 0.438 & 0.268 & 0.525 & 0.457 & 0.652 & 0.235 & 0.522 & 0.230 & 0.469 & 0.527 \\
\hline $\mathrm{Mn}$ & 0.007 & 0.013 & 0.010 & 0.006 & 0.014 & 0.013 & 0.015 & 0.008 & 0.013 & 0.007 & 0.014 & 0.015 \\
\hline $\mathrm{Mg}$ & 0.028 & 0.668 & 1.241 & 0.874 & 1.283 & 0.603 & 0.466 & 0.897 & 0.822 & 0.938 & 0.740 & 0.841 \\
\hline$\Sigma$ OCT & 1.244 & 1.269 & 1.710 & $\overline{1.229}$ & 1.842 & 1.234 & 1.268 & 1.236 & $\overline{1.419}$ & $\overline{1.251}$ & $\overline{1.311}$ & 1.434 \\
\hline $\mathrm{Ca}$ & 0.740 & 0.718 & 0.295 & 0.742 & 0.180 & 0.747 & 0.712 & 0.755 & 0.573 & 0.736 & 0.680 & 0.548 \\
\hline $\mathrm{Na}$ & 0.011 & 0.013 & - & 0.014 & - & 0.019 & 0.017 & 0.009 & 0.008 & 0.013 & 0.014 & 0.010 \\
\hline $\begin{array}{l}\text { Total } \\
\text { cations }\end{array}$ & $\overline{3.995}$ & $\overline{4.000}$ & $\overline{4.002}$ & 3.985 & $\overline{4.011}$ & 4.000 & 3.997 & 4.000 & 4.000 & 4.000 & 4.002 & 3.992 \\
\hline Quad & 93.9 & 91.6 & 96.8 & 90.7 & 96.9 & 77.6 & 78.5 & 89.2 & 91.1 & 91.9 & 88.0 & 93.9 \\
\hline Others & 6.1 & 8.4 & 3.2 & 9.3 & 3.1 & 22.4 & 21.5 & 10.8 & 8.9 & 8.1 & 12.0 & 6.1 \\
\hline Wo & 38.5 & 37.5 & 15.0 & 39.4 & 9.0 & 41.3 & 38.9 & 40.0 & 29.9 & 38.6 & 36.0 & 28.6 \\
\hline En & 48.4 & 35.0 & 62.8 & 46.4 & 64.6 & 33.4 & 25.4 & 47.5 & 42.9 & 49.3 & 39.2 & 43.9 \\
\hline Fs & 13.1 & 27.5 & 22.2 & 14.2 & 26.4 & 25.3 & 34.7 & 12.5 & 27.2 & 12.1 & 24.8 & 27.5 \\
\hline $\mathrm{Ti}$ & 18.4 & 26.5 & 24.9 & 21.8 & 27.3 & 25.1 & 29.8 & 15.7 & 26.9 & 15.6 & 25.8 & 28.4 \\
\hline $\mathrm{NaM} 2$ & 12.9 & 9.5 & - & 10.4 & - & 5.7 & 5.0 & 6.6 & 6.1 & 11.5 & 7.7 & 9.7 \\
\hline Al4 & 68.7 & 64.0 & 75.1 & 67.8 & 72.7 & 69.2 & 65.2 & 77.7 & 67.0 & 72.9 & 66.5 & 61.9 \\
\hline $\begin{array}{l}\text { Best name } \\
\text { for others }\end{array}$ & $\begin{array}{l}\text { CAMG- } \\
\text { TAL }\end{array}$ & $\begin{array}{l}\text { CAMG- } \\
\text { TAL }\end{array}$ & $\begin{array}{l}\text { MG- } \\
\text { TAL }\end{array}$ & $\begin{array}{l}\text { CAMG- } \\
\text { TAL }\end{array}$ & $\begin{array}{l}\text { MG- } \\
\text { TAL }\end{array}$ & $\begin{array}{l}\text { CAMG- } \\
\text { TAL }\end{array}$ & $\begin{array}{l}\text { CAF 2- } \\
\text { TAL }\end{array}$ & $\begin{array}{l}\text { CAF3- } \\
\text { CATS }\end{array}$ & $\begin{array}{l}\text { CAMG- } \\
\text { TAL }\end{array}$ & $\begin{array}{l}\text { CAF3- } \\
\text { CATS }\end{array}$ & $\begin{array}{l}\text { CAMG- } \\
\text { TAL }\end{array}$ & $\begin{array}{l}\text { CAMG- } \\
\text { TAL }\end{array}$ \\
\hline
\end{tabular}

orthoclase component is $4 \%$ in late-stage feldspars. Overall, there may be a trend in $\mathrm{Ca}$ content of the plagioclase phenocryst cores as a function of position in the basalt section which may indicate cooling unit contacts (Figure 8). Further detailed analyses may show more clear-cut trends with respect to An-content variations.

Most samples in Hole 319A show an increase in "Fe"/("Fe" $+\mathrm{Mg}$ ) with increasing $\mathrm{Na}$ in the feldspars. In addition, some samples show a marked drop in "Fe" (" $\mathrm{Fe} "+\mathrm{Mg}$ ) in late stages (Figure 9). The increase in "Fe" $/(" \mathrm{Fe}$ " $+\mathrm{Mg}$ ) generally is the result of decreasing $\mathrm{Mg}$ content with albite enrichment. In Sample 6-1, 145-
$148 \mathrm{~cm}$, however, in which pyroxene crystallization is mainly restricted to fine intergranular crystals, $\mathrm{Mg}$ increases with increasing $\mathrm{Na} . \mathrm{Mg}$ in plagioclase essentially remains constant in the upper part of the 12.5-meter cooling unit.

\section{Hole 320B}

Plagioclase phenocryst cores are $A_{76}-70$ in the two samples studied. Phenocryst rims and groundmass feldspars show similar ranges in composition in both samples (Figure 8). Plagioclase compositions throughout the crystallization sequence are limited to a fairly narrow range (An76-59), reflecting rapid cooling. 
TABLE 3A

Representative Plagioclase Microprobe Analyses, Hole 319A

\begin{tabular}{|c|c|c|c|c|c|c|c|c|c|c|c|c|}
\hline \multirow[b]{2}{*}{$\mathrm{SiO}_{2}$} & \multicolumn{2}{|c|}{$1-1,23-26 \mathrm{~cm}$} & \multicolumn{4}{|c|}{ 15.6-Meter Unit } & \multicolumn{2}{|c|}{ 12.5-Meter Unit } & \multicolumn{2}{|c|}{$6-1,145-148 \mathrm{~cm}$} & \multicolumn{2}{|c|}{$7-1,68-71 \mathrm{~cm}$} \\
\hline & 50.0 & 59.1 & 48.0 & 52.2 & 52.9 & 54.6 & 47.0 & 56.9 & 48.4 & 53.6 & 50.0 & 57.4 \\
\hline $\mathrm{Al}_{2} \mathrm{O}_{3}$ & 31.0 & 24.8 & 34.2 & 30.0 & 29.6 & 28.8 & 32.6 & 26.2 & 30.6 & 28.3 & 30.5 & 25.4 \\
\hline "FeO" & 0.50 & 0.87 & 0.50 & 0.63 & 0.71 & 0.74 & 0.54 & 1.03 & 0.40 & 1.11 & 1.03 & 1.34 \\
\hline $\mathrm{MgO}$ & 0.32 & 0.05 & 0.12 & 0.14 & 0.21 & 0.08 & 0.17 & 0.07 & 0.25 & 0.38 & 0.26 & 0.10 \\
\hline $\mathrm{CaO}$ & 14.4 & 8.33 & 16.3 & 13.9 & 11.9 & 11.6 & 16.0 & 8.95 & 17.8 & 12.2 & 14.9 & 8.18 \\
\hline $\mathrm{Na}_{2} \mathrm{O}$ & 3.09 & 6.64 & 1.91 & 3.59 & 4.39 & 4.91 & 1.93 & 6.17 & 2.34 & 3.98 & 3.02 & 6.54 \\
\hline $\mathrm{K}_{2} \mathrm{O}$ & - & 0.08 & 0.02 & 0.05 & 0.03 & 0.05 & 0.01 & 0.06 & - & 0.04 & 0.04 & 0.10 \\
\hline$\Sigma$ & 99.31 & 99.87 & 101.05 & 100.51 & 99.74 & 100.78 & 99.15 & 99.38 & 99.79 & 99.61 & 99.75 & 99.06 \\
\hline $\mathrm{Si}$ & 2.297 & 2.652 & 2.178 & 2.365 & 2.406 & 2.453 & 2.214 & 2.576 & 2.238 & 2.441 & 2.300 & 2.607 \\
\hline $\mathrm{Al}$ & 1.679 & 1.313 & 1.829 & 1.601 & 1.584 & 1.523 & 1.774 & 1.397 & 1.670 & 1.519 & 1.651 & 1.360 \\
\hline "Fe" & 0.019 & 0.033 & 0.019 & 0.024 & 0.027 & 0.028 & 0.021 & 0.039 & 0.016 & 0.042 & 0.040 & 0.051 \\
\hline $\mathrm{Mg}$ & 0.022 & 0.003 & 0.008 & 0.010 & 0.014 & 0.006 & 0.011 & 0.005 & 0.017 & 0.026 & 0.018 & 0.007 \\
\hline $\mathrm{Ca}$ & 0.708 & 0.400 & 0.790 & 0.678 & 0.577 & 0.560 & 0.792 & 0.434 & 0.882 & 0.596 & 0.732 & 0.398 \\
\hline $\mathrm{Na}$ & 0.275 & 0.577 & 0.168 & 0.315 & 0.387 & 0.427 & 0.173 & 0.542 & 0.200 & 0.352 & 0.269 & 0.576 \\
\hline K & - & 0.005 & 0.001 & 0.003 & 0.002 & 0.003 & 0.001 & 0.004 & - & 0.002 & 0.002 & 0.006 \\
\hline$\Sigma$ & 5.000 & 4.983 & 4.993 & $\overline{4.996}$ & 4.997 & $\overline{5.000}$ & $\overline{4.986}$ & 4.997 & $\overline{5.023}$ & 4.978 & 5.012 & 5.005 \\
\hline Or & - & 0.5 & 0.1 & 0.3 & 0.2 & 0.3 & 0.1 & 0.4 & - & 0.3 & 0.2 & 0.6 \\
\hline $\mathrm{Ab}$ & 28.0 & 58.8 & 17.5 & 31.7 & 40.1 & 43.2 & 17.9 & 55.3 & 19.2 & 37.0 & 26.8 & 58.8 \\
\hline An & 72.0 & 40.7 & 82.4 & 68.0 & 59.7 & 56.5 & 82.0 & 44.3 & 80.8 & 62.7 & 73.0 & 40.6 \\
\hline
\end{tabular}

TABLE 3B

Representative Plagioclase Microprobe Analyses, Hole 320B

\begin{tabular}{lcc|cc}
\hline & \multicolumn{2}{c|}{$3-1,136-139 \mathrm{~cm}$} & \multicolumn{2}{c}{$4-1,144-147 \mathrm{~cm}$} \\
\hline $\mathrm{SiO}_{2}$ & 50.2 & 53.5 & 50.9 & 55.3 \\
$\mathrm{Al}_{2} \mathrm{O}_{3}$ & 31.3 & 27.6 & 31.4 & 28.2 \\
"FeO" & 0.62 & 1.54 & 0.49 & 0.85 \\
$\mathrm{MgO}$ & 0.20 & 0.66 & 0.22 & 0.22 \\
$\mathrm{CaO}$ & 14.4 & 11.8 & 13.7 & 11.9 \\
$\mathrm{Na}_{2} \mathrm{O}$ & 2.90 & 4.29 & 2.72 & 4.59 \\
$\mathrm{~K}_{2} \mathrm{O}$ & 0.02 & 0.13 & 0.03 & 0.05 \\
$\Sigma$ & 99.64 & 99.52 & 99.46 & 101.11 \\
& & & & \\
$\mathrm{Si}$ & 2.297 & 2.447 & 2.320 & 2.477 \\
$\mathrm{Al}$ & 1.690 & 1.489 & 1.690 & 1.487 \\
"Fe" & 0.024 & 0.059 & 0.019 & 0.032 \\
$\mathrm{Mg}$ & 0.014 & 0.045 & 0.015 & 0.015 \\
$\mathrm{Ca}$ & 0.704 & 0.576 & 0.670 & 0.569 \\
$\mathrm{Na}$ & 0.258 & 0.381 & 0.241 & 0.399 \\
$\mathrm{~K}$ & 0.001 & 0.007 & 0.002 & 0.003 \\
\cline { 2 - 4 }$\Sigma$ & 4.988 & 5.004 & 4.957 & 4.982 \\
$\mathrm{Or}$ & 0.1 & 0.8 & 0.2 & 0.3 \\
$\mathrm{Ab}$ & 26.8 & 39.5 & 26.4 & 41.1 \\
$\mathrm{An}$ & 73.1 & 59.7 & 73.4 & 58.6 \\
\hline
\end{tabular}

The basic difference in feldspar compositions between the two samples is in "Fe"/("Fe" +Mg). The lower sample (4-1, 144-147 cm) shows an almost constant ratio in the phenocryst cores. This ratio, however, sharply increases with increased $A b$ in the groundmass stage due to an increase of $\mathrm{Mg}$ at a greater rate than that of "Fe." These differences may be attributed to the crystallization of greater amounts of pyroxene in the lower than in the upper sample, which may be a reflection of relative quench rates between the two samples (a higher rate favoring metastable pyroxene and less plagioclase).

\section{Site 321}

Plagioclase phenocryst cores in Site 321 basalts range in composition from $\mathrm{An}_{70}$ to An64. Like Hole 320B plagioclases, those from Site 321 show a narrower range in compositions than do the more slowly cooled plagioclase from Hole 319A (Figure 8). Again, at Site 321, the maximum An content of phenocrysts shows somewhat of a consistent trend with depth in the stratigraphic section. "Fe"/("Fe" $+\mathrm{Mg}$ ) increases with increasing $\mathrm{Na}$ throughout the crystallization sequence due to a decrease in $\mathrm{Mg}$ with increasing $\mathrm{Na}$.

\section{Intersite Comparisons}

The obvious difference among the three sites in terms of feldspar chemistry is the narrower range of plagioclase compositions in Hole 320B basalts compared to the other two sites, presumably reflecting the more quickly chilled character of these basalts relative to those from the other sites. Late-stage (vesicle-filling and interstitial) feldspars are enriched in $\mathrm{Na}$ relative to earlier feldspars in any sample studied, but Or contents never exceed 4 mole $\%$ even in the late stages. The " $\mathrm{Fe}$ "/("Fe" $+\mathrm{Mg}$ ) ratio for Site 321 feldspars shows a continuous increase with crystallization into the vesiclefilling stage compared to a decrease in this ratio in the latest stages in Hole 319A.

Feldspar compositional data may be consistent with textural evidence in terms of delineating different cooling units at all three sampling sites. Compositional breaks in plagioclase are present at assumed unit contacts. In the 15.6-meter unit in Hole 319A, there appears to be an anomalous compositional range in the feldspars in the upper part of this unit which is also reflected in 
TABLE 3C

Representative Plagioclase Microprobe Analyses, Site 321

\begin{tabular}{|c|c|c|c|c|c|c|c|c|}
\hline \multirow[b]{2}{*}{$\mathrm{SiO}_{2}$} & \multicolumn{2}{|c|}{$14-1,55-58 \mathrm{~cm}$} & \multicolumn{2}{|c|}{$14-1,99-102 \mathrm{~cm}$} & \multicolumn{2}{|c|}{$14-4,12-15 \mathrm{~cm}$} & \multicolumn{2}{|c|}{$14-4,35-38 \mathrm{~cm}$} \\
\hline & 51.6 & 60.0 & 52.4 & 57.9 & 51.7 & 55.8 & 52.5 & 55.1 \\
\hline $\mathrm{Al}_{2} \mathrm{O}_{3}$ & 30.2 & 24.4 & 30.5 & 26.4 & 29.8 & 27.7 & 30.5 & 28.3 \\
\hline$" \mathrm{FeO} "$ & 0.78 & 0.72 & 0.70 & 1.27 & 0.83 & 0.88 & 0.77 & 1.30 \\
\hline $\mathrm{MgO}$ & 0.21 & 0.07 & 0.19 & 0.14 & 0.16 & 0.07 & 0.13 & 0.10 \\
\hline $\mathrm{CaO}$ & 14.2 & 8.38 & 13.8 & 9.48 & 14.4 & 10.1 & 12.7 & 10.7 \\
\hline $\mathrm{Na}_{2} \mathrm{O}$ & 3.46 & 6.54 & 3.31 & 5.85 & 3.63 & 5.58 & 3.81 & 5.16 \\
\hline $\mathrm{K}_{2} \mathrm{O}$ & 0.03 & 0.11 & 0.02 & 0.09 & 0.05 & 0.10 & 0.04 & 0.09 \\
\hline$\Sigma$ & 100.48 & 100.22 & 100.92 & 101.13 & 100.57 & 100.23 & 100.45 & 100.75 \\
\hline $\mathrm{Si}$ & 2.344 & 2.679 & 2.360 & 2.578 & 2.351 & 2.512 & 2.373 & 2.476 \\
\hline $\mathrm{Al}$ & 1.617 & 1.283 & 1.619 & 1.387 & 1.596 & 1.469 & 1.623 & 1.501 \\
\hline "Fe" & 0.030 & 0.027 & 0.027 & 0.047 & 0.032 & 0.033 & 0.029 & 0.049 \\
\hline $\mathrm{Mg}$ & 0.014 & 0.005 & 0.013 & 0.010 & 0.011 & 0.005 & 0.009 & 0.007 \\
\hline $\mathrm{Ca}$ & 0.690 & 0.401 & 0.668 & 0.452 & 0.699 & 0.488 & 0.614 & 0.514 \\
\hline $\mathrm{Na}$ & 0.305 & 0.566 & 0.289 & 0.505 & 0.320 & 0.487 & 0.334 & 0.449 \\
\hline K & 0.002 & 0.006 & 0.001 & 0.005 & 0.003 & 0.006 & 0.003 & 0.005 \\
\hline$\Sigma$ & 5.002 & 4.967 & 4.977 & 4.984 & 5.012 & 5.000 & 4.985 & 5.001 \\
\hline Or & 0.2 & 0.6 & 0.1 & 0.5 & 0.3 & 0.6 & 0.3 & 0.5 \\
\hline $\mathrm{Ab}$ & 30.6 & 58.2 & 30.2 & 52.5 & 31.3 & 49.7 & 35.1 & 46.4 \\
\hline An & 69.2 & 41.2 & 69.7 & 57.0 & 68.4 & 49.7 & 64.6 & 53.1 \\
\hline
\end{tabular}

TABLE 4

Representative Olivine Microprobe Analyses, Hole 319A

\begin{tabular}{lc|c|c|cc}
\hline & $3-3,64-67 \mathrm{~cm}$ & $3-3,110-113 \mathrm{~cm}$ & $4-1,126-126 \mathrm{~cm}$ & \multicolumn{2}{|c}{$5-1,84-87 \mathrm{~cm}$} \\
\hline $\mathrm{SiO}_{2}$ & 39.2 & 36.8 & 39.4 & 39.4 & 37.4 \\
$\mathrm{FeO}$ & 14.6 & 27.5 & 17.1 & 16.4 & 22.9 \\
$\mathrm{MnO}$ & 0.21 & 0.35 & 0.30 & 0.24 & 0.38 \\
$\mathrm{MgO}$ & 46.2 & 35.8 & 42.2 & 44.4 & 38.8 \\
$\mathrm{CaO}$ & 0.33 & 0.31 & 0.33 & 0.36 & 0.37 \\
$\Sigma$ & 100.54 & 100.76 & 99.33 & 100.80 & 99.85 \\
$\mathrm{Si}$ & 0.980 & 0.977 & 1.005 & 0.984 & 0.982 \\
$\mathrm{Fe}$ & 0.306 & 0.611 & 0.366 & 0.346 & 0.501 \\
$\mathrm{Mn}$ & 0.004 & 0.008 & 0.007 & 0.005 & 0.008 \\
$\mathrm{Mg}$ & 1.721 & 1.415 & 1.608 & 1.671 & 1.516 \\
$\mathrm{Ca}$ & 0.009 & 0.009 & 0.009 & $\underline{0.009}$ & 0.010 \\
$\Sigma$ & 3.020 & 3.020 & 2.995 & 3.015 & 3.017 \\
$\mathrm{Fo}$ & 84.7 & 69.6 & 81.2 & 82.6 & 74.8 \\
$\mathrm{Fa}$ & 15.3 & 30.4 & 18.8 & 17.4 & 25.2 \\
\hline
\end{tabular}

the higher initial $\mathrm{Na}$ (relative to $\mathrm{A} 14$ and $\mathrm{Ti}$ ) in pyroxenes of the same sample.

\section{Olivines}

Olivines have been analyzed only from parts of the Hole 319A basalt section, and this phase has not been identified in any of our samples from Hole 320B and Site 321 . Unaltered olivine is very rare above the lower half of the 15.6-meter cooling unit at Hole 319A; near the bottom of this basalt section, olivine commonly is too small to analyze.

Olivine relicts near the center of the 15.6-meter cooling unit do not appear to be significantly zoned (Fo85-82) (Figure 4), but appear to be zoned lower in the cooling unit (3-3, 110-113 cm). Petrographically, it appears as if smectite pseudomorphs after olivine increase in abun- dance towards the bottom of this cooling unit (as well as modal olivine), and this may suggest that crystal fractionation has taken place in this unit. Crystal fractionation is also supported by preliminary (unpublished) feldspar data on Sample 3-4, 136-139 cm which indicates more calcic phenocryst core compositions near the bottom of the unit. In the 12.5 -meter unit, olivines are only slightly more forsteritic near the bottom, and the modal abundance of olivine increases towards the bottom. Zoned olivines (Fo82-75) are also found in Sample 5-1, $84-87 \mathrm{~cm}$.

\section{Opaque Oxides}

Titanomagnetites were analyzed in samples from all sites, but relatively few analyses were possible in the Hole 320B samples because of small grain sizes. Titano- 
TABLE 5A

Fe-Ti Oxide Microprobe Analy ses, Hole 319A

\begin{tabular}{|c|c|c|c|c|c|c|}
\hline & \multicolumn{4}{|c|}{ Titanomagnetites } & \multicolumn{2}{|c|}{ Ilmenites } \\
\hline & $\begin{array}{c}2-2, \\
87-90 \mathrm{~cm}\end{array}$ & $\begin{array}{c}3-3, \\
64-67 \mathrm{~cm}\end{array}$ & $\begin{array}{c}5-1 \\
84-87 \mathrm{~cm}\end{array}$ & $\begin{array}{c}4-1, \\
123-126 \mathrm{~cm}\end{array}$ & $\begin{array}{c}3-2 \\
104-107 \mathrm{~cm}\end{array}$ & $\begin{array}{c}2-2, \\
87-90 \mathrm{~cm}\end{array}$ \\
\hline $\mathrm{SiO}_{2}$ & 0.16 & - & 0.07 & 0.08 & - & - \\
\hline $\mathrm{Al}_{2} \mathrm{O}_{3}$ & 1.74 & 1.92 & 1.56 & 1.64 & 0.18 & - \\
\hline $\mathrm{TiO}_{2}$ & 26.2 & 25.3 & 25.6 & 23.4 & 50.3 & 49.9 \\
\hline "FeO" & 65.2 & 65.1 & 66.5 & 70.8 & 43.4 & 47.4 \\
\hline $\mathrm{MnO}$ & 0.69 & 0.57 & 0.49 & 0.54 & 0.75 & 0.67 \\
\hline $\mathrm{MgO}$ & 0.30 & 1.12 & 0.79 & 0.68 & 0.51 & 0.16 \\
\hline $\mathrm{Cr}_{2} \mathrm{O}_{3}$ & 0.02 & - & 0.01 & 0.06 & 0.02 & - \\
\hline$\Sigma$ & 94.31 & 94.01 & 95.02 & 97.20 & 95.16 & 98.13 \\
\hline
\end{tabular}

TABLE 5B

Representative Microprobe

Analyses of Opaque Minerals,

Sample 320B-4-1, 144-147 cm

\begin{tabular}{lc|c}
\hline \multicolumn{2}{l|}{ Titanomagnetite } & Cr-Spinel \\
\hline $\mathrm{SiO}_{2}$ & 0.09 & - \\
$\mathrm{Al}_{2} \mathrm{O}_{3}$ & 1.87 & 24.9 \\
$\mathrm{TiO}_{2}$ & 19.1 & 1.08 \\
$\mathrm{FeO}$ & 70.5 & 22.9 \\
$\mathrm{MnO}$ & 0.42 & 0.13 \\
$\mathrm{MgO}$ & 0.71 & 14.3 \\
$\mathrm{Cr}_{2} \mathrm{O}_{3}$ & - & 38.6 \\
$\Sigma$ & 92.69 & 101.91 \\
\hline
\end{tabular}

magnetite is a late-stage phase and often coexists with ilmenite, especially in Hole 319A.Tables 5A-C list representative $\mathrm{Fe}$ - $\mathrm{Ti}$ oxide analyses which show that throughout both Hole 319A and Site 321 titanomagnetites appear to be of fairly uniform composition. Probe traverses across several grains, and optical examination of these grains suggest that titanomagnetites are largely homogeneous, except perhaps near veins.

The only chromian spinel observed in Leg 34 samples studied, found as an inclusion in a feldspar phenocryst in Sample 320B-4-1, 144-147 cm, has been analyzed (Table 5B) and its formula, calculated on the basis of 3 cations, is $\mathrm{Mg}_{06} \mathrm{Fe}^{2+}{ }_{04} \mathrm{Fe}^{3+}{ }_{02} \mathrm{Cr}_{09} \mathrm{Al}_{09} \mathrm{O}_{4}$.

\section{CONCLUSIONS}

1. Phase chemical data are somewhat consistent with textural observations aboard ship in delineating two major cooling units in Hole 319A. However, textural changes with depth in the basalt section in this hole, as observed in our limited samples, are not conclusive.

Phase chemical data show differences in the two cooling units represented by Hole 320B samples. At least two cooling units are delineated by phase chemical data for our Site 321 representatives, although as many as three units may be inferred by pyroxene chemical variations or modal mineralogical variations (Figure 2). More detailed analyses are needed to define cooling unit boundaries in the absence of complete textural evidence from our samples.
2. Although textures range from variolitic to coarsegrained ophitic, the presence of late-stage variolitic intergrowths, interstitial (altered) glass, and significant chemical zonation in plagioclases and pyroxenes suggest fairly rapid cooling in even the thickest of the cooling units. Site 321 basalts are vesicular and uniformly fine grained.

3. Almost all Leg 34 basalts are plagioclase phyric, and Hole 319A basalts appear to be largely plagioclase and olivine phyric. Clinopyroxene may have coprecipitated with liquidus plagioclases in Site 321 basalts.

4. In all Leg 34 samples, there are two or three main stages of plagoclase growth as well as one or two main stages of clinopyroxene growth.

5. Site 321 basalts are distinctive in terms of pyroxene chemistry.

\section{ACKNOWLEDGMENTS}

The authors are indebted to M.N. Bass and S.R. Hart for their constructive criticisms of the manuscript. F.N. Hodges and R.A. Ayuso also critically reviewed this report, and M.N. Bass provided additional discussion about Leg 34 basalts. S. King and M.C. Floran typed the manuscript. This research was supported by NSF Grant No. A035450.

\section{REFERENCES}

Bass, M.N., 1974. Secondary minerals in basalt, DSDP Leg 34 (abstract): Geol. Soc. Am. Abstracts with Programs, v. 6, p. 646.

TABLE 5C

Titanomagnetite Microprobe Analyses, Site 321

\begin{tabular}{lc|c|c|c}
\hline & $\begin{array}{c}14-1, \\
55-58 \mathrm{~cm}\end{array}$ & $\begin{array}{c}14-1, \\
99-102 \mathrm{~cm}\end{array}$ & $\begin{array}{c}14-4, \\
12-15 \mathrm{~cm}\end{array}$ & $\begin{array}{c}14-4, \\
35-38 \mathrm{~cm}\end{array}$ \\
\hline $\mathrm{SiO}_{2}$ & - & 0.02 & 0.09 & 0.27 \\
$\mathrm{Al}_{2} \mathrm{O}_{3}$ & 1.60 & 2.18 & 1.88 & 1.79 \\
$\mathrm{TiO}_{2}$ & 23.1 & 24.5 & 22.9 & 24.1 \\
"FeO" & 70.2 & 65.2 & 69.6 & 68.6 \\
$\mathrm{MnO}$ & 0.47 & 0.46 & 0.65 & 0.47 \\
$\mathrm{MgO}$ & 0.49 & 0.80 & 0.31 & 0.47 \\
$\mathrm{Cr}_{2} \mathrm{O}_{3}$ & - & - & 0.08 & 0.02 \\
$\Sigma$ & 95.86 & 93.16 & 95.51 & 95.72 \\
\hline
\end{tabular}



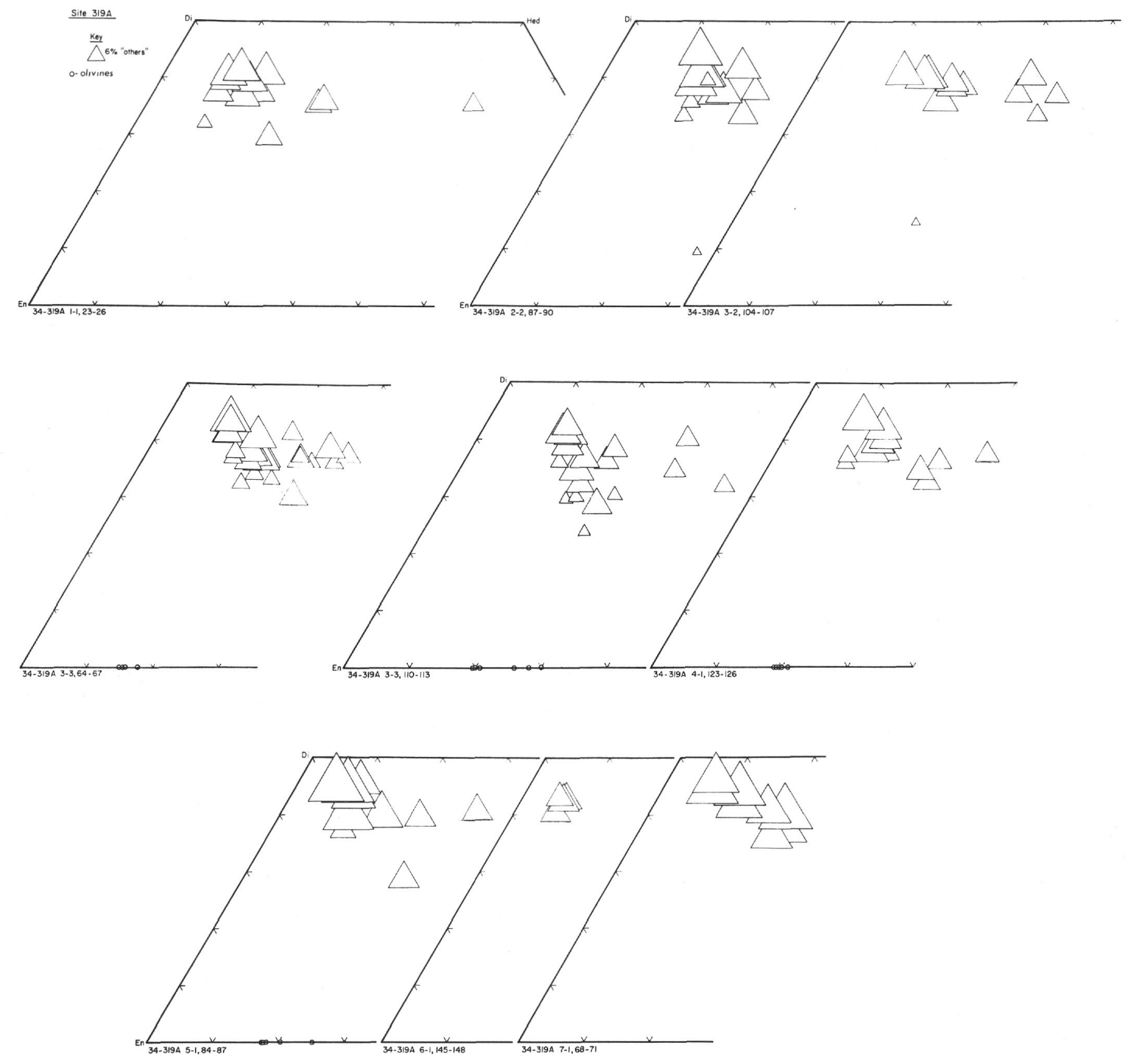

Figure 4. Pyroxene analyses plotted on the pyroxene quadrilateral and showing percentages of components other than Wo-En-Fs. Diagrams are presented in stratigraphic order. The 15.6-meter cooling unit of Hole 319A extends through Samples 2-2, 87-90 $\mathrm{cm}$ to 3-3, 110-113 $\mathrm{cm}$ and the 12.5-meter cooling unit is represented by Samples 4-1, 123-126 $\mathrm{cm}$ and 5-1, 84-87 cm. Olivine compositions, where present, are plotted along the $\mathrm{Mg}$-Fe join.

Bence, A.E. and Albee, A., 1968. Empirical correction factors for the electron microanalysis of silicates and oxides: $J$. Geol., v. 76, p. 382.

Bunch, T.E. and La Borde, R., 1974. Mineralogy and compositions of selected basalts from Site 319, Leg 34 (abstract): Geol. Soc. Am. Abstracts with Programs, v. 6, p. 673 .

Corliss, J.B., Dymond, J., Dasch, F.J., and Field, C.W., 1974. Major and trace element geochemistry, age, and isotopic studies of Leg 34 basalts (abstract): Geol. Soc. Am. Abstracts with Programs, v. 6, p. 694.

Fein, C.D., 1974. Geochemistry of basalts from Holes 319A and 321 from Leg 34 of the Deep Sea Drilling Project (abstract): Geol. Soc. Am. Abstracts with Programs, v. 6, p. 730 .

Hart, S.R., 1974. LIL-element geochemistry, Leg 34 basalts (abstract): Geol. Soc. Am. Abstracts with Programs, v. 6, p. 730 .

Hart, S.R., et al., 1974. Oceanic basalts and the Nazca plate: Geotimes, v. 19, p. 20.

Herron, E.M., 1972. Sea floor spreading and Cenozoic history of the East Central Pacific: Geol. Soc. Am. Bull., v. 83, p. 1671 .

Papike, J.J., Cameron, K.L., and Baldwin, K., 1974. Amphiboles and pyroxenes: Characterization of other than quadrilateral components and estimates of ferric iron from 

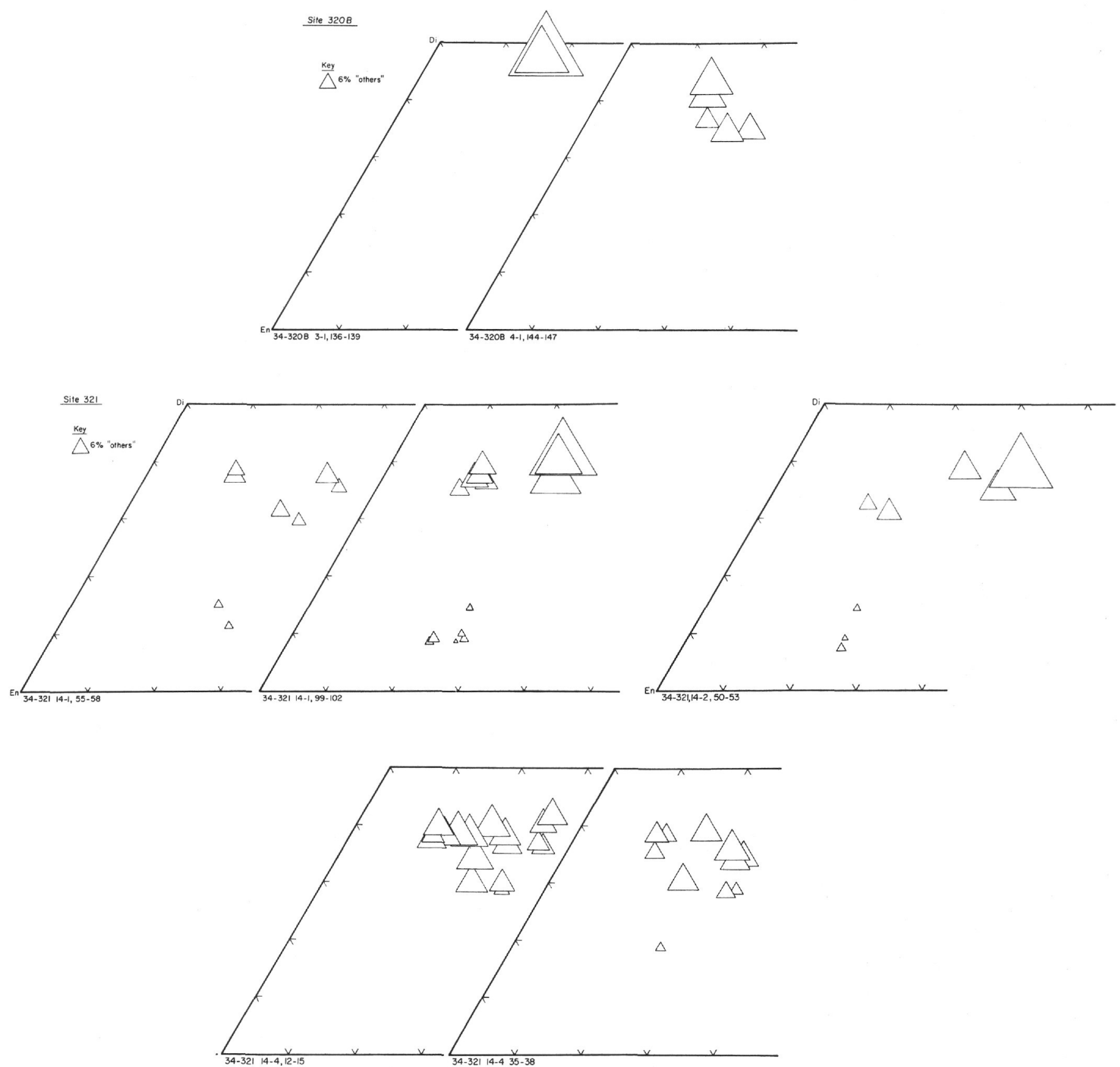

Figure 4. (Continued).

microprobe data (abstract): Geol. Soc. Am., Abstracts with Programs, v. 6, p. 1053.
Thompson, G., Bryan, W.B., Frey, F.A., Dickey, J.S., and Suen, J., 1974. Petrology and geochemistry of basalts from DSDP Leg 34, Nazca plate (abstract): Geol. Soc. Am. Abstracts with Programs, v. 6, p. 985. 

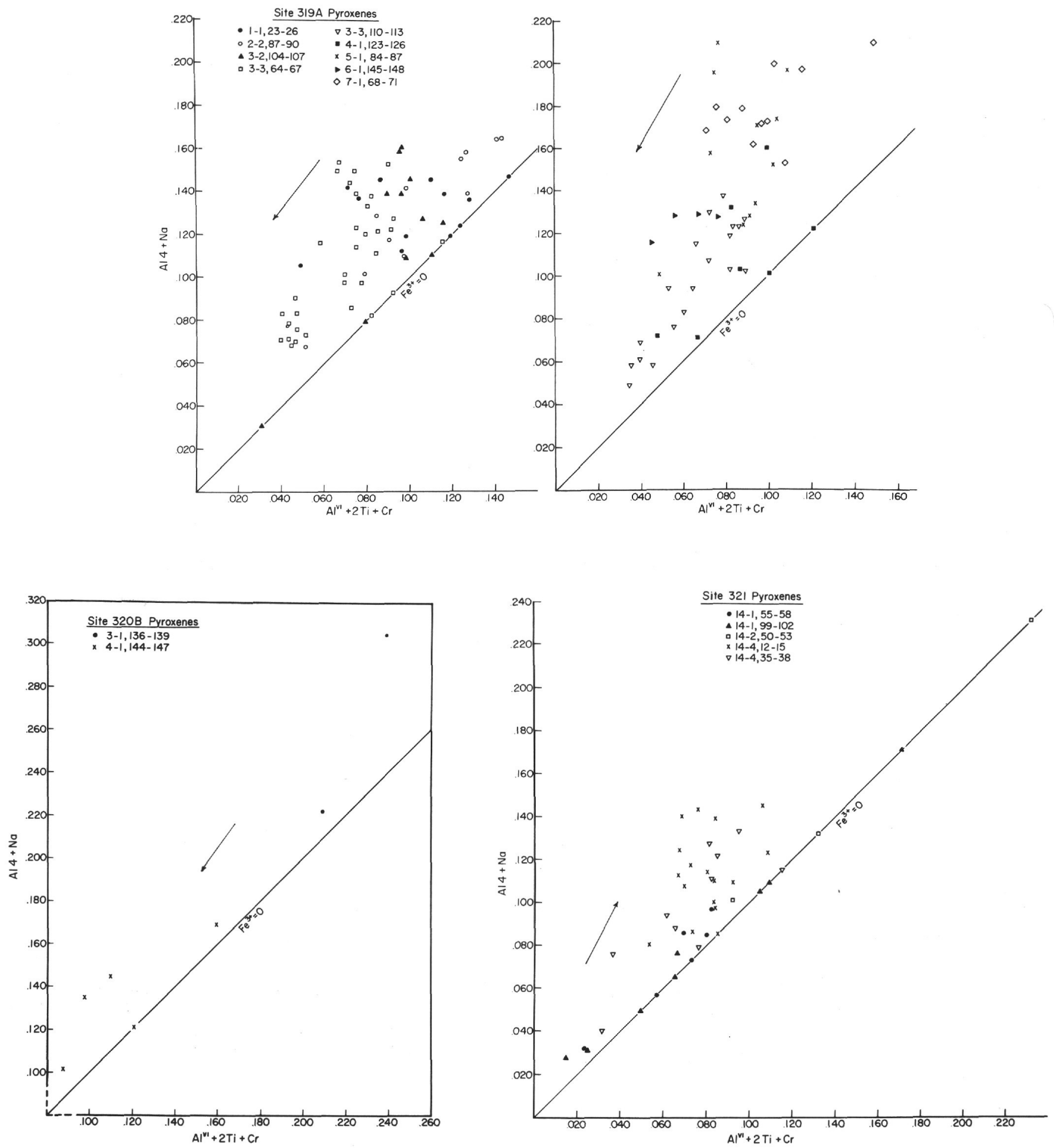

Figure 5. Diagrams showing amounts of "other" components in pyroxenes and approximate ferric iron contents (see Papike et al., 1974). The 45' line which passes through the origin is the locus of points where Fe ${ }^{3+}=0$. Arrows indicate general directions of crystallization trends. 

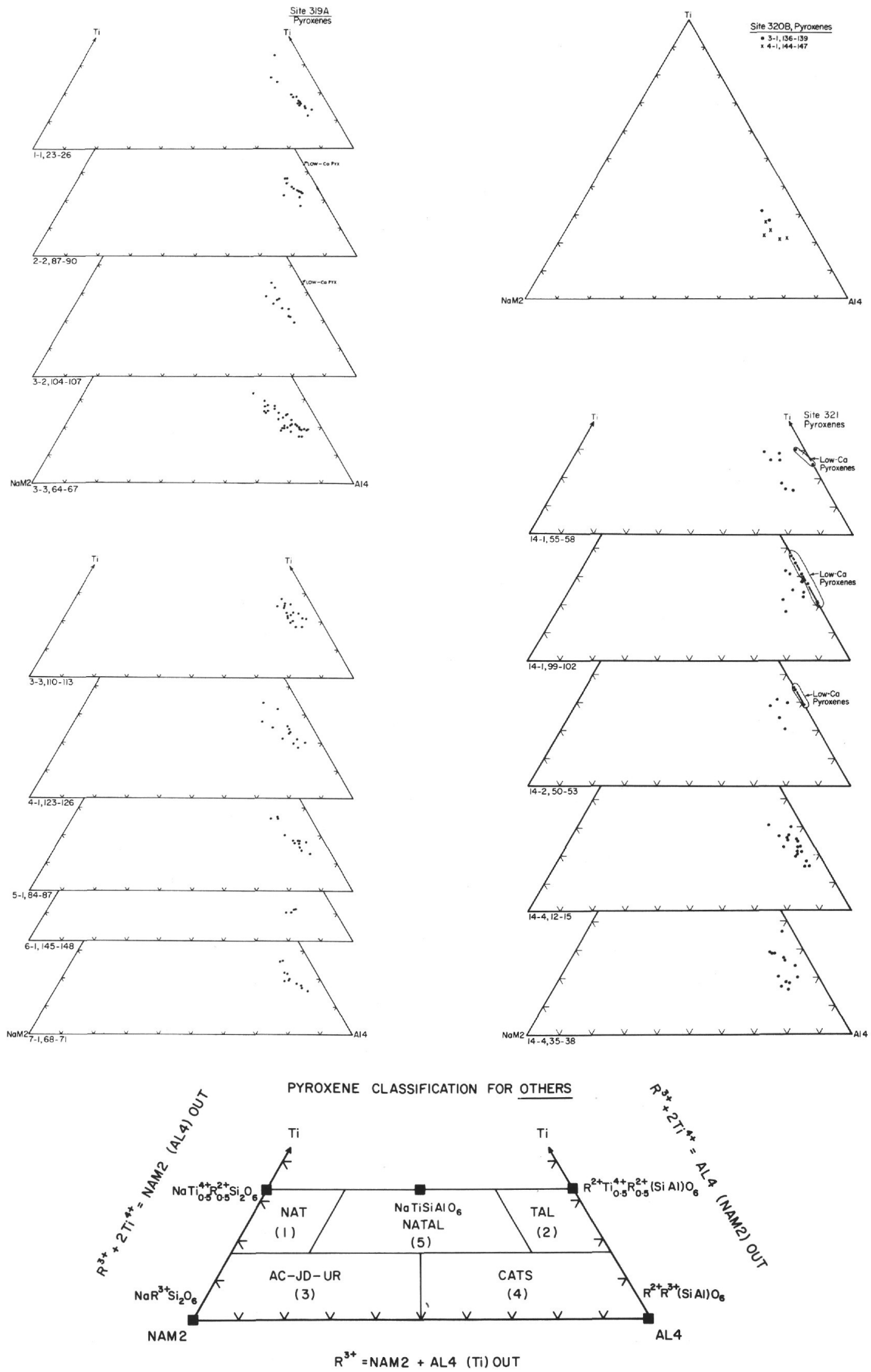

Figure 6. Ti-NaM2-A14 diagrams for Leg 34 pyroxenes and legend showing the nomenclature for pyroxene "other" components (from Papike et al., 1974). 

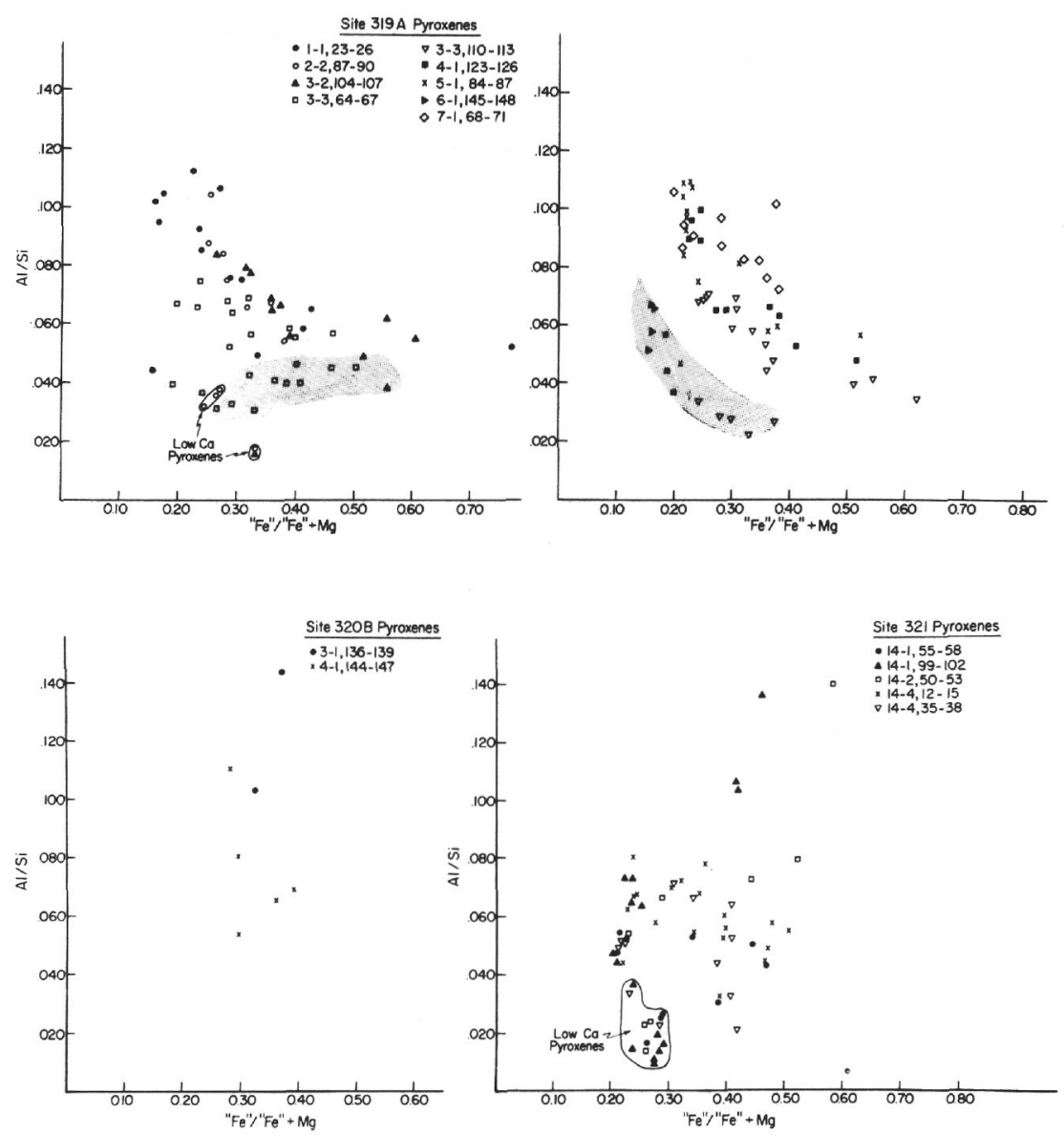

Figure 7. Al/Si versus "Fe"'/"Fe" + Mg diagrams for Leg 34 pyroxenes. Shaded areas denote zoning trends. "Fe" reported as ferrous iron. 


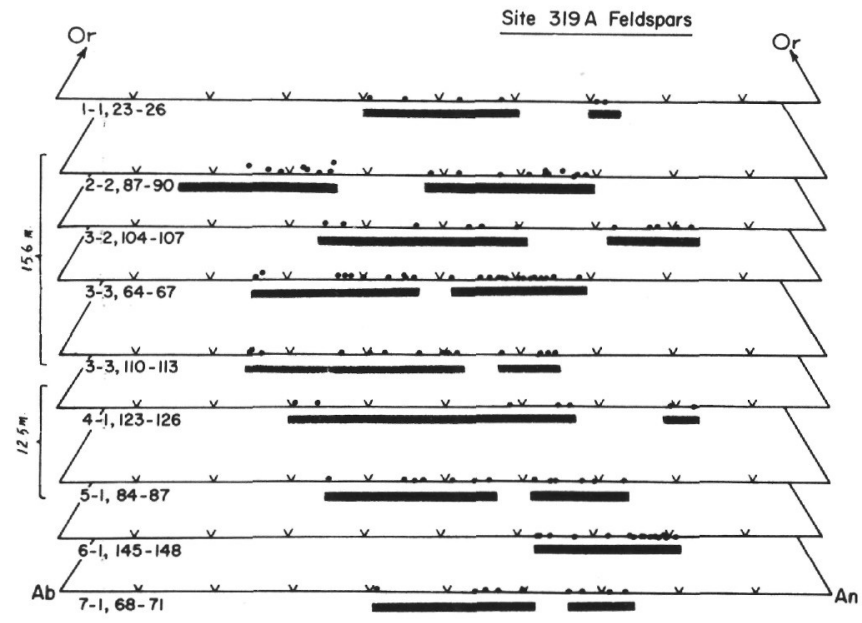

Site 3208 Feldspars

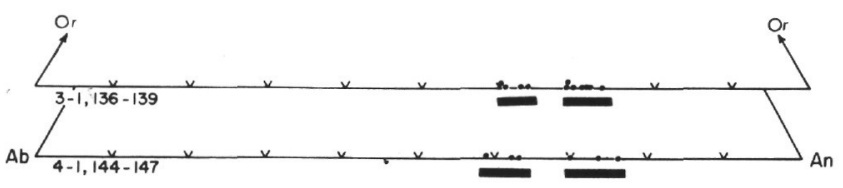

Site 321 Feldspors

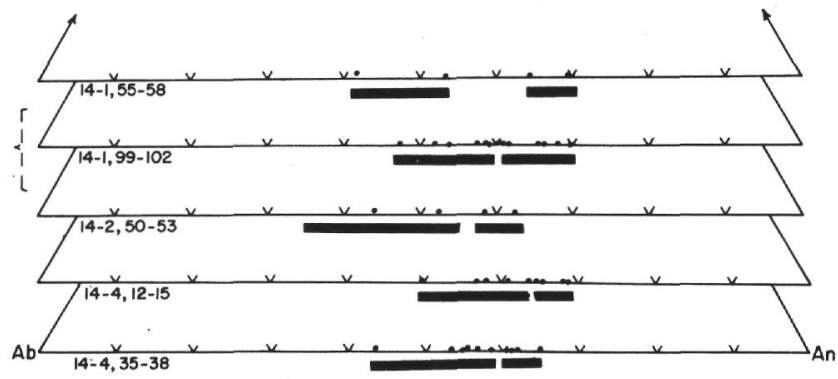

Figure 8. Plagioclase analyses plotted against relative vertical positions. Bars indicate ranges of phenocryst core compositions and rim and groundmass compositions.
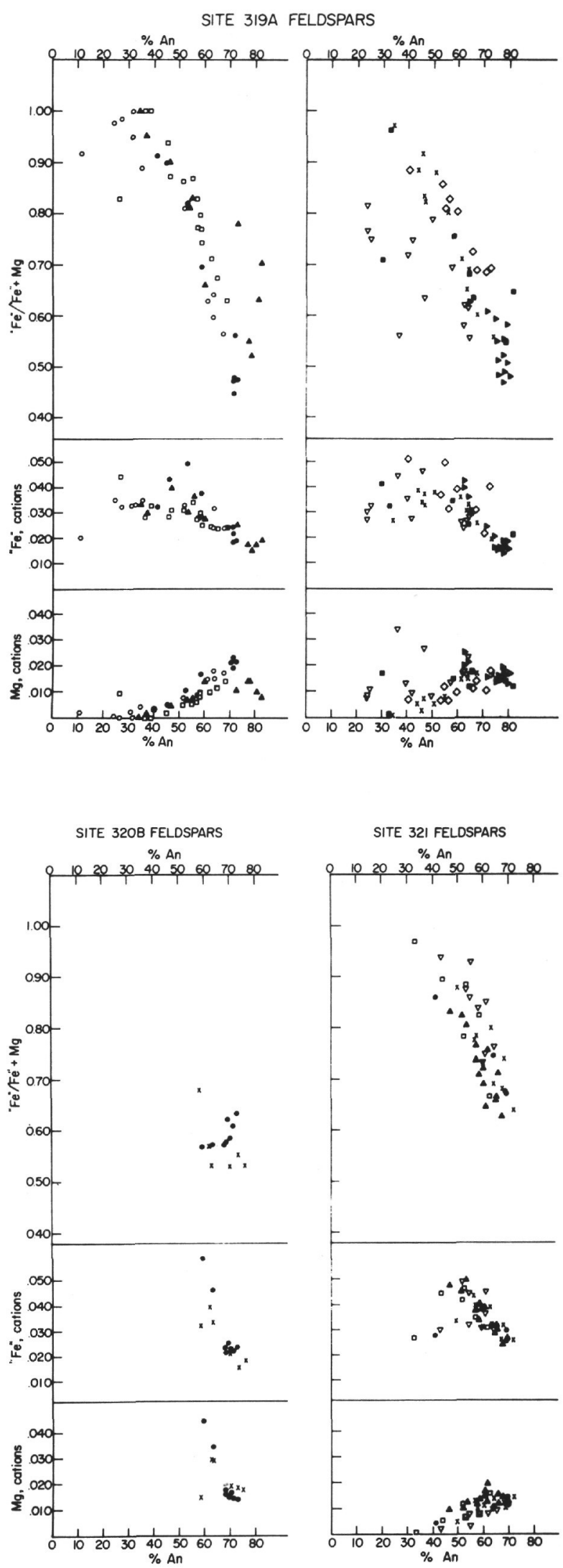

Figure 9. Anorthite content versus "Fe"/ "Fe" + $\mathrm{Mg}$, "Fe" and $\mathrm{Mg}$ for plagioclases; symbols same as in Figure 5. "Fe" reported as ferrous iron. 